\title{
Mechanistic effects of low-flow hydrology on riverine ecosystems: ecological principles and consequences of alteration
}

\author{
Robert J. Rolls ${ }^{1}$, Catherine Leigh ${ }^{2}$, AND Fran Sheldon ${ }^{3}$ \\ Australian Rivers Institute, Griffith University, Nathan 4111, Queensland, Australia
}

\begin{abstract}
Alterations to the natural flow regime affect the structure and function of rivers and wetlands and contribute to loss of biodiversity worldwide. Although the effects of flow regulation have been relatively well studied, a lack of synthesis of the ecological consequences of low flows and droughts impedes research progress and our grasp of the mechanistic effects of human-induced water reductions on riverine ecosystems. We identified 6 ecologically relevant hydrological attributes of low flow (antecedent conditions, duration, magnitude, timing and seasonality, rate of change, and frequency) that act within the temporal hierarchy of the flow regime and a spatial context. We synthesized the literature to propose 4 principles that outline the mechanistic links between these low-flow attributes and the processes and patterns within riverine ecosystems. First, low flows control the extent of physical aquatic habitat, thereby affecting the composition of biota, trophic structure, and carrying capacity. Second, low flows mediate changes in habitat conditions and water quality, which in turn, drive patterns of distribution and recruitment of biota. Third, low flows affect sources and exchange of material and energy in riverine ecosystems, thereby affecting ecosystem production and biotic composition. Last, low flows restrict connectivity and diversity of habitat, thereby increasing the importance of refugia and driving multiscale patterns in biotic diversity. These principles do not operate in isolation, and many of the ecological pathways that are affected by low flows are likely to overlap or occur simultaneously, potentially resulting in synergistic and complex effects. Last, we outlined major human-induced threats to low-flow hydrology and how they act upon the ecologically relevant hydrological attributes of low flow to affect potential changes in riverine ecosystem integrity. The mechanistic links described in this synthesis can be used to develop and test hypotheses of low-flow hydrological-ecological response relationships in a cause-effect framework that will have value for both research and river flow management. Continued experimental research and ongoing consolidation of ecological information will improve our understanding and ability to predict consequences of low-flow alteration on river, floodplain, and estuarine ecosystems.
\end{abstract}

Key words: flow regime, low flow, drought, habitat, food web, carrying capacity, connectivity, metapopulation, refugia, biodiversity, trophic cascades, biological traits.

The frequency, magnitude, duration, timing, and spatial extent of flow events are universal drivers of ecological integrity in riverine ecosystems and apply to events of both high- and low-flow magnitude. Temporal hierarchy dictates that ecological responses to short-term flow events will be strongly influenced by longer-term patterns within the context of the flow regime (Biggs et al. 2005). As extremes of the flow regime, floods and droughts act as major hydrologic disturbances for lotic ecosystems and exert significant influences on biota, ecosystem conditions, and processes (Lake 2000). Identifying relationships between

\footnotetext{
${ }^{1}$ E-mail addresses: r.rolls@griffith.edu.au

2 c.leigh@griffith.edu.au

3 f.sheldon@griffith.edu.au
}

the attributes of such phenomena and ecosystem function and patterns of biodiversity broadens our understanding of the links between hydrology and ecology and helps to inform effective management of water while preserving biodiversity (Arthington et al. 2006).

Alterations to the natural flow regime affect the structure and function of rivers and wetlands and contribute to loss of biodiversity worldwide (Bunn and Arthington 2002). Our understanding of the effects of flow disturbance, and by extension, alteration of flow regime on riverine ecosystems has derived primarily from ecological studies of average and high-flow events (Lake 2000). Empirical research into the effects of low flows and drought is increasing rapidly as management of limited water becomes a 
greater challenge, but a lack of synthesis of the ecological consequences of low flows, including droughts, remains. Therefore, the mechanistic effects of human-induced water reductions on riverine ecosystems are poorly grasped (Boulton and Lake 2008). Given this deficiency and the fact that the low-flow end of the hydrograph is vulnerable to alteration caused by human-driven changes to the flow regime (Smakhtin 2001), rectifying this knowledge gap is imperative.

The aim of our synthesis is to improve our conceptual understanding of human-induced alterations to low-flow hydrology that result in changes to aquatic ecosystems and our ability to predict ecological responses to low-flow events within the context of natural and altered low-flow regimes. We first identify the attributes of low-flow hydrology that are ecologically relevant for riverine biota and ecosystem processes. We then synthesize the global literature to propose 4 principles of low-flow ecohydrology that outline the mechanisms by which these biota and ecosystem processes respond to the hydrological attributes of low flows. These principles act within the context of longer-term flow conditions and the spatial hierarchy of the river network (sensu Frissell et al. 1986, Biggs et al. 2005). Last, we emphasize the human-induced alterations to lowflows that threaten the ecological integrity of riverine ecosystems. Previous authors (Dewson et al. 2007a, Suren and Riis 2010) have reviewed the consequences of decreased flows on in-stream habitat, water quality, and the corresponding changes to specific groups of aquatic taxa. However, we synthesize the literature across multiple taxonomic groups and the physical and chemical processes that influence patterns of biodiversity and ecosystem function.

\section{Ecologically Relevant Attributes of Low-Flow Hydrology}

Identifying attributes of the flow regime that are ecologically relevant is a common goal of ecohydrological research. For example, environmental flow methods are used primarily to identify relationships between flow characteristics and patterns or processes in river ecosystems (Arthington et al. 2006). The broad aims of users of such methods are to predict the condition of ecosystems under specific flow scenarios, to identify particular ecological thresholds in the responses to flow, and to evaluate whether flowecology relationships can be modeled in some way. In the context of low flows, such relationships can be defined by the nature of the low-flow disturbance as either a press (constant) or ramp disturbance (sustained and cumulative) in contrast to a pulse disturbance (applied then released) (Lake 2003). However, flow regimes are complex in space and time, so generalizing low-flow ecology relationships through time at large spatial scales is likely to be challenging. Thus, these relationships may be more easily identified at regional or context-specific scales. Through our review of the literature, we identified 6 ecologically relevant hydrological attributes of low flow (antecedent conditions, duration, magnitude, timing and seasonality, rate of change, and frequency) but acknowledge that these act within the temporal hierarchy of the flow regime and a spatial context (Fig. 1A-C).

\section{Antecedent conditions}

Antecedent conditions constitute the hydrological characteristics to which aquatic biota and their habitats are exposed prior to each hydrological disturbance event. Antecedent flow patterns and long-term characteristics of the flow regime help determine ecological responses to individual flow events (Biggs et al. 2005). For example, Fritz and Dodds (2005) suggested that under typical hydrological conditions in intermittent prairie streams (Kansas, USA), macroinvertebrate assemblage structure is most strongly driven by historical hydrological characteristics. When recent flow events are atypical, such as unusually low flows, ecological responses may be more pronounced. This interplay between antecedent hydrology and ecological response is related to the life-history, behavioral, and morphological adaptations of the biota resident within a particular landscape that have evolved within the context of the natural flow regime (Lytle and Poff 2004). Therefore, historical factors cannot be separated from the responses of aquatic biota to individual lowor high-flow events. When low-flow periods are more extreme than those experienced on average, biota may not possess the adaptations necessary for adequate resistance or resilience. This situation creates potential opportunities for invasions by taxa able to tolerate and persist in the changed conditions. For example, antecedent flow permanence was critical in determining the invertebrate community response to supraseasonal low flows in Derbyshire streams, UK (Stubbington et al. 2009). An invasive crayfish species had greater resistance to drying in streams than a native species, which was less tolerant of desiccation (Larson et al. 2009). Increased flow intermittency can alter the herbaceous species composition in floodplains such that more drought-tolerant, introduced species (e.g., Tamarix) increase in dominance (Stromberg et al. 2007). Furthermore, Rogers et al. 

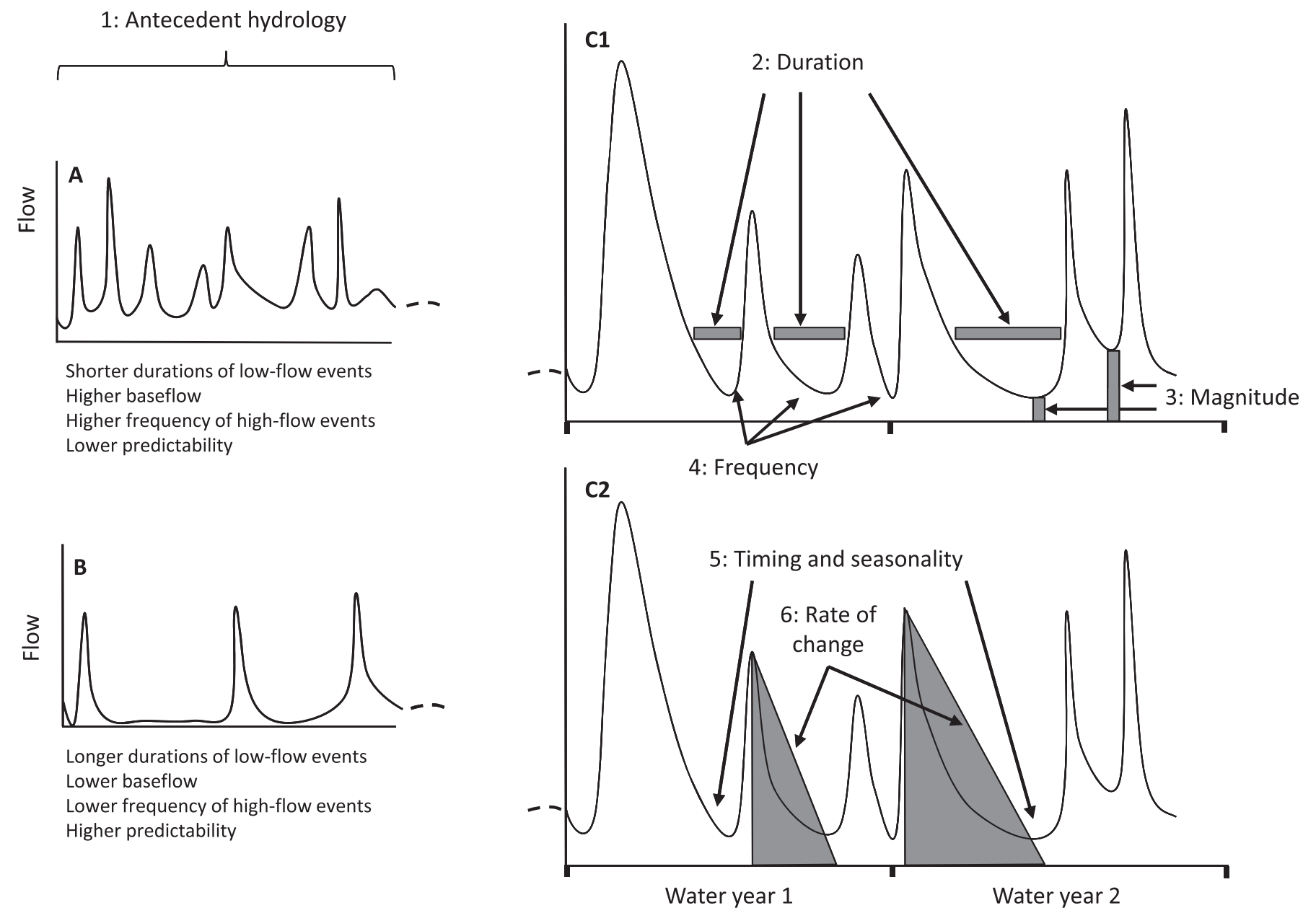

Longer durations of low-flow events Lower baseflow Lower frequency of high-flow events Higher predictability

Water year 1

Water year 2

FIG. 1. Schematic hydrographs describing variation within, and interactions between, ecologically important low-flow attributes, and the integration of sequential low-flow events within the flow regime. A.-Antecedent hydrology in a system with short durations of low-flow events interspersed with frequent high-flow events. B.-Antecedent hydrology in a system with longterm low flow and infrequent floods. C1.- Schematic representation of duration, magnitude, and frequency of periods of low flow. C2.-Schematic representation of seasonality and timing of periods of low flow and rate of change in the hydrograph.

(2005) suggested that sequential years of low flows have adverse effects on fish species with short life spans and recruitment strategies that depend on minimum discharge thresholds. However, our understanding of long-term in-stream ecological responses to extreme and sustained low flows, such as supraseasonal droughts in perennial rivers, is incomplete (Wood and Armitage 2004) relative to our understanding of responses to floods (Matthaei and Townsend 2000).

\section{Duration}

Effects of low-flow events on aquatic ecosystems tend to intensify with increasing duration (ramp disturbances; e.g., droughts), whereby low-flow events with longer duration have more significant ecological impacts than events of shorter duration.
Increased duration of low flow or absence of flow has been associated with change and decreased species richness of macroinvertebrate assemblages (Larned et al. 2007, Arscott et al. 2010, Datry 2012) accompanied by colonization and increased biomass of macrophytes (Suren and Riis 2010). Conversely, indicators of richness and diversity of biotic assemblages typically increase with increasing flow permanence, which decreases the cumulative duration of low flow (Feminella 1996). For example, in the Waipara River, New Zealand, increased duration of low flow had significant negative effects on fish abundance, whereas short-term periods of low flow had relatively subtle effects (Jowett et al. 2005). Therefore, increased duration of moderate low flow may have more significant ecological consequences than a short period of severe low flow. 


\section{Magnitude}

The magnitude of river discharge $\left(\mathrm{ML} / \mathrm{d}, \mathrm{m}^{3} / \mathrm{s}\right)$ is widely used to set minimum flows to maintain ecosystem health and function. However, a small \% change in low-flow magnitude may cause a disproportionately large change in ecological response. For example, in an experimental flow-diversion study in New Zealand, a reduction in discharge by up to $90 \%$ caused relatively few effects on macroinvertebrate abundance and composition (James and Suren 2009), whereas in the USA, discharge reductions of $96 \%$ from mean conditions corresponded with a 60 to $67 \%$ reduction in brook trout (Salvelinus fontinalis) densities and growth rates (Hakala and Hartman 2004). These results suggest that different thresholds of low-flow discharge (probably interacting with duration) may induce different ecological responses. Change in lowflow magnitude also can interact with river and catchment characteristics to produce different scales of response. For example, reductions in baseflow discharges affected fish species richness and density more severely in smaller (low-order) than in larger (higherorder) streams in Georgia, USA (McCargo and Peterson 2010). Thus, the scales and particulars of ecological responses to changes in low-flow magnitude may depend somewhat on landscape features and other, broad-scale factors, such as biogeographic context.

\section{Timing and seasonality}

Timing of low-flow events can have significant consequences on recruitment and migration of aquatic biota, particularly if low flows occur during migration periods and restrict dispersal (e.g., McDowall 1995). Thus, differences in the timing and seasonality of low-flow events will produce different effects on patterns and processes in aquatic ecosystems. For example, low flows during winter had little effect on habitat use and movement of juvenile cutthroat trout (Oncorhynchus clarki) and brown trout (Salmo trutta) in the USA (Dare et al. 2002), but low flows during summer growth periods can reduce growth of brook trout and rainbow trout (Oncorhynchus mykiss) (Harvey et al. 2006, Sotiropoulos et al. 2006, see also McCargo and Peterson 2010). Thus, low flows may have little ecological effect in some seasons or times, but riverine ecosystems and biota are likely to be more sensitive to low flows during periods of naturally higher productivity and dispersal.

\section{Rate of change}

The rate (e.g., change in discharge/d) of flow recession promotes rapid shifts in abiotic conditions and critically influences the ability of mobile biota to access refugia. Biota become increasingly vulnerable to stranding or desiccation as the rate of flow recession increases. For example, an increased rate of flow recession (drawdown) was correlated with increased mortality of riverine fish in New Zealand (Davey et al. 2006) and Canada (Bradford 1997). Abrupt flow stoppages during construction and maintenance of dams and weirs can cause rapid dewatering of river channels that result in high fish mortality caused by stranding on bare substrate or in shallow pools (Bishop and Bell 1978). In addition, rivers with high rates of water withdrawal often are characterized by a reduced proportion of fluvial species or biota that feed on riffle benthos (Kanno and Vokoun 2010). These studies suggest that when flow recession is rapid and leads to the sudden onset of low-flow conditions or cease-to-flow events, many riverine biota are likely to be adversely affected.

\section{Frequency}

The frequency of low-flow events forms a key biological filter for the persistence of biota, whereby species that are unable to tolerate or persist after low flows are unlikely to occur in rivers or regions where low flows are relatively frequent (and, in some cases, persistent), such as dryland and ephemeral rivers. For example, in experimental chalk-stream mesocosms in the UK, increasing the frequency of 6-d low-flow events from 99- to 33-d cycles reduced algal cell densities and eliminated desiccation-intolerant taxa after just 1 to 2 drying cycles compared with the low-frequency drying and control treatments (Ledger et al. 2008). Therefore, rivers that experience frequent and regular periods of low flows are likely to support biota that are capable of persisting through low-flow disturbances (of durations typically experienced) and show only subtle or short-term changes in response to each low-flow event. In contrast, rivers that rarely experience ecologically critical low-flow magnitudes are likely to support a greater proportion of taxa with life-history traits that are unsuited to survival under conditions of low flow and show more significant effects of individual low-flow events. For example, macroinvertebrate and fish assemblages in small streams in California showed significant and persistent changes following a single 5-y drought that was similar in magnitude to only 2 other events that occurred over the $\sim 50-y$ antecedent period (Bêche et al. 2009). Thus, such trends also are linked to antecedent hydrology and the adaptations of biota that allow them to survive low flows and drought. 


\section{Spatial context}

Low flows occur over a range of spatial scales, from river reaches that are hundreds of meters long to entire river networks. Within networks, low flows may occur in headwaters, mid-reaches, and lowland reaches (Lake 2003), or any possible combination of these regions. The spatial extent of low flows will affect the range and type of ecological responses to them.

Refugia act as sources for biotic recovery after lowflow events (Magoulick and Kobza 2003, Sheldon et al. 2010). Therefore, the spatial locations of lowflow refugia within the landscape and river network are critical to the recovery of biota from low-flow disturbances. For example, proximity to low-flow refugia in rivers determined the rate of recovery of fish in the Selwyn River, New Zealand (Davey and Kelly 2007). In addition, different fish species presumably moved to refugia in different directions (upstream vs downstream), thereby increasing the risk of species extinction if the refugial habitats were lost. In small rivers, the removal or absence of refugia for benthic algae during drought has been linked to reduced algal densities and slowed growth after resumption of flow (Robson and Matthews 2004). In large rivers, complete drying of river reaches and floodplain water bodies that provide low-flow refugia for aquatic biota threatens regional persistence of both aquatic and terrestrial species (Bunn et al. 2006), particularly those with (or reliant upon those with) low resistance to desiccation (Arthington and Balcombe 2011).

\section{Mechanistic Links Between Low Flow and Aquatic Ecosystems}

Having identified the ecologically relevant attributes of low-flow hydrology, we now outline the causal links between low flows and ecological responses within riverine ecosystems. We summarize these links into 4 principles below (Fig. 2).

Principle 1: Low flows control the extent of physical aquatic habitat, thereby influencing the composition and diversity of biota, trophic structure, and carrying capacity.

Structural composition and biological traits.-River discharge controls the diversity, availability, and area of habitats, such as riffles, runs, pools, backwaters, and floodplains. Effects of flows on aquatic habitats depend on the local-scale interaction between hydrology and geomorphology, mediated by changes in hydraulic conditions. Low flows reduce volume, area, and depth of aquatic habitat and change the instantaneous velocity of rivers. The spatial dimensions of fastflowing habitats, such as riffles, are most susceptible to changes in low-flow conditions. For example, in headwater streams in West Virginia, USA, a 96\% reduction in discharge resulted in a $52 \%$ reduction of riffle habitat area but only a $2 \%$ reduction in pool habitat area (Hakala and Hartman 2004). Low flows also reduce, limit, or eliminate river-floodplain connectivity (Tockner et al. 1999, van der Nat et al. 2002).

Effects of low flows on aquatic ecosystems are directly or indirectly linked to changes in aquatic habitats and the processes that occur within them. As flow magnitude recedes and habitat area and volume contract, short-term increases in abundance and richness of biota (per unit space) are frequently observed, particularly for invertebrates and fish (Stubbington et al. 2011). During experimental flow abstractions in streams in New Zealand conducted over $1 \mathrm{mo}$, total benthic macroinvertebrate densities increased by 37 to $59 \%$, whereas densities of individual species increased by up to $851 \%$ compared with densities in control reaches (Dewson et al. 2007c). Richness of benthic macroinvertebrates peaks immediately before streams cease to flow (Acuña et al. 2005). In addition, macroinvertebrate densities and richness are often highest in riffles with comparatively slow water velocity because of the combined effects of reduced drag on organisms and increased standing stock of primary producers, which provide both food and shelter (Brooks et al. 2005). Therefore, low flows often induce short-term, positive changes (increases) in population- and assemblage-level structural attributes.

Reduced flow magnitude results in lower instantaneous flow velocity across habitats in streams (Dewson et al. 2007a). Reduced flow velocity has 2 key consequences across streams: 1) it reduces the capacity of the stream to transport silt and fine sediment, and 2) it allows establishment of aquatic plants (algae and macrophytes). Reduced capacity to transport silt and fine sediment leads to increased benthic sedimentation as the duration of stable lowflow events increases (Dewson et al. 2007d, James et al. 2008a). Sedimentation can disrupt hydrological connection between surface and ground waters (Boulton 2007), potentially increasing the diel range in water temperature because of limited thermal buffering by groundwater contributions to flow. Siltation reduces mesohabitat heterogeneity (Kemp et al. 2011), and increases similarities among pool, run, and riffle assemblages (Berkman and Rabeni 1987). Sedimentation can influence recruitment by smothering eggs deposited in substrate, can reduce dissolved $\mathrm{O}_{2}$ (DO) (e.g., because of reduced hydrological exchange between surface and hyporheic zones), and can 


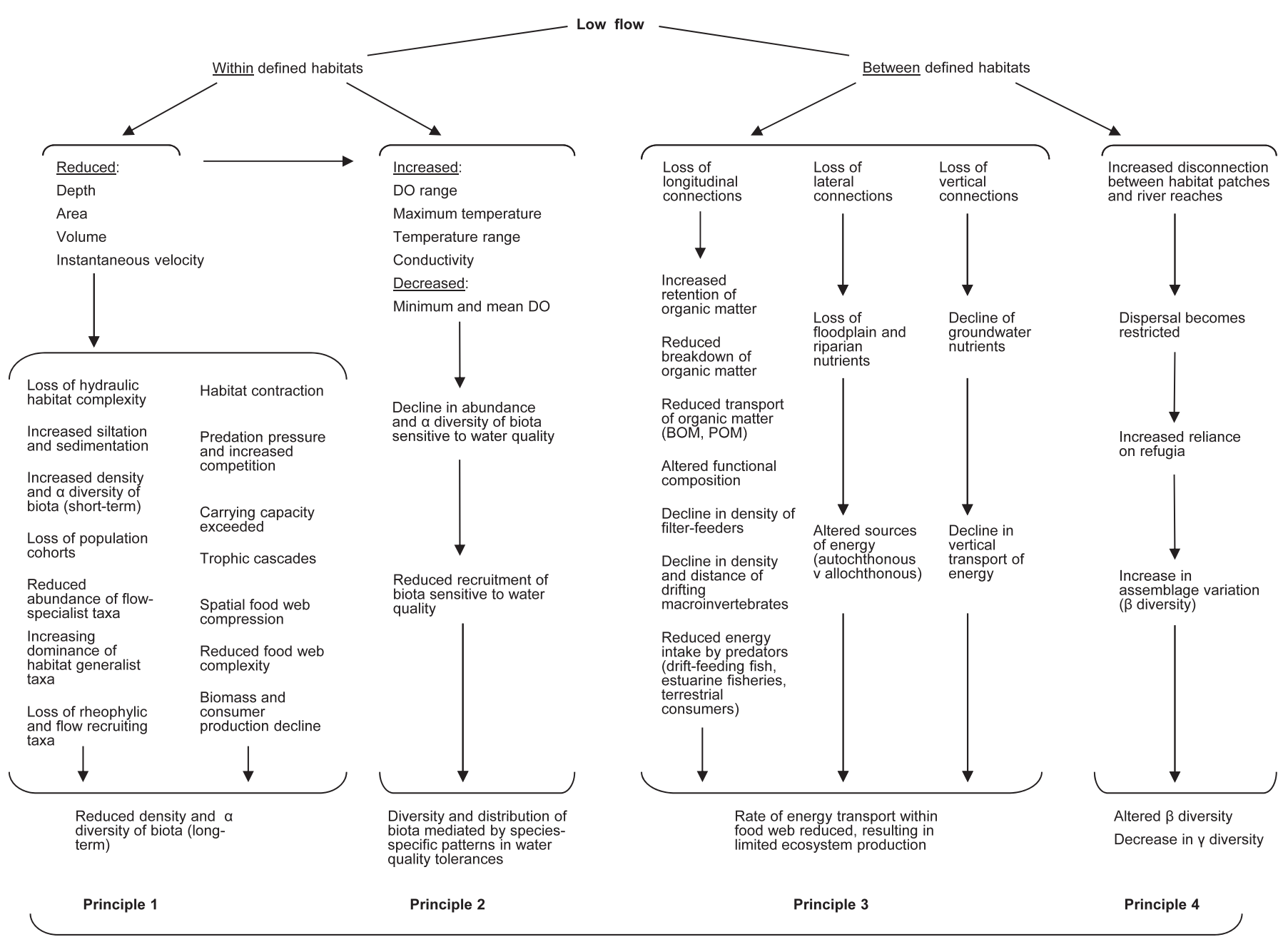

FIG. 2. Four principles outlining the broad mechanistic links between low flow and processes and patterns in riverine ecosystems. These links do not operate in isolation, and many ecological pathways that are affected by low flows are likely to occur simultaneously, potentially resulting in similar or synergistic and complex effects. $\mathrm{DO}=$ dissolved $\mathrm{O}_{2}, \mathrm{BOM}=$ benthic organic matter, $\mathrm{POM}=$ particulate organic matter.

reduce stream depth (Owens et al. 2005, Kemp et al. 2011).

Established macrophyte beds may compound the effects of low flows by further reducing flow velocity and increasing sediment accrual. For example, flow velocities within beds of the aquatic macrophyte Ranunculus were $<0.1 \mathrm{~m} / \mathrm{s}$, whereas velocities were up to $0.8 \mathrm{~m} / \mathrm{s}$ outside the beds, and fine sediment continued to accumulate within the beds over the course of the annual growing season (Cotton et al. 2006). Thus, a feedback loop can occur such that low flows lead to fine sediment accumulation, which encourages macrophyte establishment and growth, which further slows the flow velocities, which leads to more fine sediment accumulation, and so on. Macrophyte cover is often highest in reaches with low variability of flow and long periods of low flow. In contrast, rivers with a high frequency of high-flow disturbances (floods) or high flow variability tend to be characterized by reduced macrophyte cover (Riis et al. 2008). Algal biomass can be higher during prolonged periods of few floods and increased duration of low flow than during other flow periods (Biggs and Stokseth 1996). This increase may lead to changes in trophic status or can be associated with blooms of harmful cyanobacteria, which have ramifications for water-quality management and ecosystemlevel functioning, e.g., trophic cascades and regime shifts (Scheffer and Carpenter 2003, Baldwin et al. 2010, Paerl et al. 2011).

Extended duration of low-flow events is associated with a progressive loss of total aquatic habitat and, in particular, of fast-flowing habitat. As a consequence, prolonged low flows are associated with reduced 
densities of flow-dependent taxa (Haxton and Findlay 2008) and can lead to an overall loss of species richness and total assemblage density. These responses are particularly consistent for aquatic macroinvertebrates and fish, and to a lesser extent, algae and macrophytes. Rheophilic taxa are among the most susceptible to changes in low-flow conditions (Haxton and Findlay 2008, Brooks et al. 2011) and show reduced densities and richness in flow-abstracted reaches compared to control reaches. Examples of this phenomenon have been reported from Australia (McKay and King 2006, Finn et al. 2009), New Zealand (Suren et al. 2003a), Europe (Castella et al. 1995), and the USA (Miller et al. 2007). Shifts in fish abundances have been associated specifically with changes in availability of flowing habitat in the Waipara River, New Zealand, where fast-flowing riffle-dwelling species showed the greatest negative change during extended low-flow periods and abundances of species with low-velocity preferences increased (Jowett et al. 2005). Increased frequency of low flows also alters the composition of algal assemblages by favoring desiccation-resistant taxa (Burns and Walker 2000, Ledger et al. 2008). With increasing duration of low flows, biotic diversity consistently declines as flow-dependent taxa are lost from the species pool, resulting in low-diversity assemblages dominated by low-flowresistant taxa (Brooks et al. 2011).

When low flows occur naturally over extended durations such that habitats contract or even disappear, selection processes will favor species capable of maintaining recruitment processes under such conditions. For example, many Australian freshwater fish species spawn and recruit during periods of stable low flows (Pusey et al. 2004) or are able to maintain populations by recruiting during low flows despite their ability to increase recruitment during high flows or floodplain inundation (Humphries et al. 1999). On a continuum of flow permanence (\% time for which a river is in flow) and duration (length of time in flow), rivers with lower flow permanence and duration (e.g., many streams and rivers in Mediterranean climates) tend to have higher proportions of taxa with short life spans, small body size, low fecundity, and multiplebatch recruitment (multivoltine reproduction) (Bonada et al. 2007, Arscott et al. 2010). For example, smallerbodied macroinvertebrates with multivoltine recruitment patterns were more abundant in ephemeral streams that flowed only during and immediately after irregular rain events than in intermittent streams that flowed for much of the year but receded into isolated pools during the dry season (Chakona et al. 2008).

Extended low flows also have been associated with loss of juvenile or adult cohorts of fish because of loss of preferred habitat. In some cases, young-of-the-year cohorts show the greatest reduction in abundance during low flows (e.g., Hakala and Hartman 2004, Riley et al. 2009), whereas in others, larger size classes show the greatest decline, possibly because of loss of habitat or reduced growth resulting from a decline in food sources (Elliott et al. 1997).

Effects of low flows extend beyond in-stream biota. Densities and recruitment of water birds are often driven by patterns in hydrology. For example, mean numbers of water birds declined by 23 to $98 \%$ over $24 \mathrm{y}$ in eastern Australia, a decline associated with increased water abstraction that caused a reduction of available aquatic habitat despite no significant change in rainfall (Nebel et al. 2008). Greater diversity and abundances of riparian arthropods in arid regions occur in river reaches with flowing water than in reaches that are completely dry (e.g., McCluney and Sabo 2012).

Trophic structure and carrying capacity.-As habitat dimensions decrease during low flow, the concentration of mobile aquatic biota increases, resulting in increased competition and predation pressure. Therefore, low flows exert a strong effect on trophic carrying capacity (i.e., maximum potential biomass that can be supported by available energy). During stream drying in the USA, fish densities were negatively associated with maximum pool area and depth (Dekar and Magoulick 2007), indicating that density of consumers and, therefore, predation pressure increased during at least the initial phases of habitat contraction. However, under persistent low flows caused by 75 y of flow regulation in France, biomass and numerical densities of brown trout were positively related to the depth and area of habitat, and carrying capacity of fish was reduced during low flow (Baran et al. 1995). Thus, densities of biota are often increased by habitat contraction during initial periods of low flow with subsequent decline in densities over protracted low-flow periods.

Increased concentration of consumers or predators caused by reduced habitat volume under low flow can lead to increased competition for energy sources. Therefore, carrying capacity of biota during low flows is controlled by both physical-habitat effects and by biotic effects mediated through habitat effects. Fish consumed a lower diversity and biomass of prey in intermittent than in permanent rivers in Spain and preferentially selected prey with low relative abundances (Mas-Martí et al. 2010). Limited food resources have been attributed as the cause of reduced densities of brook trout during low flows (Hakala and Hartman 2004). The richness of benthic-feeding fish species is more sensitive to water abstraction than richness of 
pelagic feeders in Mediterranean streams (Benejam et al. 2010), indicating that the carrying capacity in rivers is limited during periods of low flow.

Foodweb structure and trophic linkages are driven by flow regime in riverine ecosystems. As habitat area and volume decline with reduced flow, food webs become spatially compressed and the number of trophic levels that can be sustained is predicted to decrease (McCann et al. 2005). Trophic complexity also is influenced by flow regime and particularly by high frequency of low flows. Rivers with highly intermittent flow regimes can be characterized by reduced foodweb complexity during and after periods of low flow (Closs and Lake 1994). Low flows also contribute to reduced trophic complexity in estuaries (Livingston 1997, Vinagre et al. 2011).

Trophic cascades in rivers are most apparent during stable baseflow conditions. For example, during base flow in streams in the USA, predators reduced the direct grazing pressure of primary consumers on benthic algae, resulting in high algal biomass (Power et al. 1985, 2008, Power 1990). Topdown and bottom-up trophic cascades occur in rivers under low flow. For example, the presence of predatory fish negatively affected macroinvertebrate densities during low flows in Zimbabwe, which led to increased densities of zooplankton (a top-down trophic cascade; Nhiwatiwa et al. 2009). Conversely, reduced densities of macroinvertebrates caused by reduced habitat, poor water quality, or both can contribute to declines in fish biomass (bottom-up control; Livingston 1997, McIntosh et al. 2003).

\section{Principle 2: Low flows mediate changes in habitat} conditions, which in turn, drive patterns in the distribution and recruitment of biota.

River discharge interacts with seasonal patterns to cause significant changes in water-quality variables (Sheldon and Fellows 2010). The distribution, abundance, and recruitment of aquatic biota are, in turn, affected by differences in physical and chemical water-quality tolerance thresholds, which result in spatial and temporal patterns of biotic distributions. Low flows typically are associated with reduced DO, high diel maxima and ranges in water temperature, and high electrical conductivity. In addition, multiple changes in water-quality variables occur simultaneously during low flows.

Lowest DO levels often occur when flow ceases (Cowx et al. 1984, Boulton and Lake 1990, van Vliet and Zwolsman 2008), and DO declines in river reaches subject to low-flow water abstraction (McKay and King 2006, Dewson et al. 2007c). When lowest flows are associated with highest air temperatures and are compounded by reduced water volumes, reduced thermal buffering and high water temperatures often result. For example, summer means of maximum and minimum water temperatures in pools in Wilfin Beck, UK, were both $\sim 10^{\circ} \mathrm{C}$ higher in drought years than in nondrought years (Elliott 2000). Discharge also is negatively correlated with electrical conductivity and salinity in rivers and estuaries because of the diluting effect of freshwater inputs (although this effect may depend on the biogeochemistry of source waters). In the Umatilla River, USA, electrical conductivity increased with flow extraction when flow extraction was $>85 \%$ of available discharge (Miller et al. 2007). Conductivity can increase 5 to $11 \times$ between sites upstream and downstream of flow diversion points (Rader and Belish 1999). Some macroinvertebrate taxa are sensitive to high conductivity, but whether this intolerance is to conductivity per se or to pollutants and increased nutrient concentrations, which produce the high conductivities, is unclear (Miller et al. 2007). Such multiple and often simultaneous changes in water quality can make identifying the specifics of water-quality-mediated changes in aquatic ecosystems difficult because often little information on the tolerance thresholds of individual species is available.

Biota that are sensitive to changes in water quality (e.g., Ephemeroptera, Plecoptera, and Trichoptera [EPT] macroinvertebrates) are often particularly affected by low flows. For example, in an undisturbed stream in New Zealand, density of EPT taxa decreased in response to declines in DO and increased conductivity associated with experimental low-flow extraction when compared with control sites (Dewson et al. 2007b). EPT richness declined in river reaches in the USA where low flows contributed to reduced water quality (Miller et al. 2007). Reproduction and recruitment of water-quality-sensitive taxa also can be affected by low-flow events. In temperate streams of Victoria, Australia, reduced recruitment of Plecoptera and Trichoptera was detected in the year following a 6-mo drought (Boulton and Lake 1992b). Similar patterns have been observed elsewhere; e.g., in the Afon Dulas, UK, reduced recruitment of Plecoptera (and Coleoptera) and loss of young-of-the-year Atlantic salmon (Salmo salar) was detected in the year following a 3-mo drought (Cowx et al. 1984). These effects were attributed to sustained elevated water temperatures.

Thermal stratification, long residence times, and reduced vertical mixing of the water column in the main channel of rivers during low flows can drive production of phytoplankton and cyanobacteria, 
thereby contributing to significant and widespread occurrences of phytoplankton blooms associated with eutrophication during low flow (e.g., as measured by nutrient and chlorophyll $a$ concentrations; Alpine and Cloern 1992, van Vliet and Zwolsman 2008). Severe cyanobacterial blooms during low flow coupled with high $\mathrm{P}$ and low $\mathrm{O}_{2}$ concentrations affected almost $1000 \mathrm{~km}$ of the Barwon-Darling River, MurrayDarling Basin, Australia during the 1991-1992 summer. The bloom was so substantial that it remained for $\sim 2$ mo until it was flushed from the river by increases in flow (Bowling and Baker 1996). Low water temperatures tend to restrict the magnitude of algal production in rivers, whereas blooms are typically greatest under low-to-moderate flow velocities during periods of higher water temperatures and light availability (Paerl and Huisman 2008, Salmaso and Braioni 2008). However, biomass of benthic and planktonic algae during low flows also may be limited by nutrient availability (Suren et al. 2003b, Townsend and Padovan 2005, Townsend et al. 2012).

Patterns in the distribution of freshwater and estuarine fishes often reflect water-quality tolerances of individual taxa, and the effects of low flows on biota often are attributed to patterns in water quality. For example, high water temperatures affect the distributions of particular fish species. Mortality of salmonids has been associated with elevated temperatures during summer (Connor et al. 2003, Gunn and Snucins 2010), and fish survival increases with stream flow (Connor et al. 2003, Xu et al. 2010). Low flows are thought to minimize the effect of alien brown trout on several Galaxias species in Australia and New Zealand. Brown trout are unable to tolerate water temperatures as high as those that native galaxiids can tolerate, so low-flow areas create trout-free refugia for Galaxias (Closs and Lake 1996, Leprieur et al. 2006).

Low flow in intermittent or temporary streams occasionally results in hypoxic, or near-hypoxic, conditions (Chessman and Robinson 1987, Closs and Lake 1996), which may be associated with other factors besides lowered velocities and turbulence, including die off of algal blooms. The effects of these events can be long lasting because many taxa are unable to tolerate low DO for sustained periods and, thus, may be lost from the assemblage for some time. Freshwater fish have a minimum threshold for DO, often at $\sim 1$ to $2 \mathrm{mg} \mathrm{O}_{2} / \mathrm{L}$ (Dean and Richardson 1999, McNeil and Closs 2007). For example, fish in floodplain backwaters of the upper Mississippi River, USA, avoid habitats with DO $<2 \mathrm{mg} / \mathrm{L}$ (Knights et al. 1995). The distribution of blue crabs (Callinectes sapidus) in estuaries in the USA is restricted to regions with $\mathrm{DO}>2.4 \mathrm{mg} / \mathrm{L}$ (Selberg et al. 2001). These findings suggest that persistence and distribution of riverine species during low-flow periods can be predicted based on water-quality tolerances when they are known (e.g., Crook et al. 2010). However, some species can persist under hypoxic conditions by means of water-surface respiration (McNeil and Closs 2007).

Principle 3: Low flows affect the sources and exchange of energy in riverine ecosystems, thereby affecting ecosystem production and biotic composition.

Transport of energy to, from, and within surfacewater ecosystems provides nutrients necessary to sustain aquatic ecosystems and ecosystem production. Flow mediates the transport of nutrients laterally from riparian and floodplain habitats, vertically between substrates and fluid habitats, and longitudinally between habitats and reaches.

Longitudinal connections.-Discharge of water influences longitudinal transport of energy and organic matter in streams. Low flows retard the rate of longitudinal energy flow. In particular, low flows increase the retention of benthic organic matter (BOM), such as leaves and small woody debris (Dewson et al. 2007b) because the low flows are not capable of suspending the material and moving it downstream. Changes in the proportions of macroinvertebrate functional feeding groups often reflect patterns in resource availability (Boulton and Lake 1992a). Densities of detritivores, shredders, and scrapers may increase because of increased retention and accumulation of allochthonous organic matter during prolonged low flows. For example, the relative abundance of shredders was $\sim 3.5 \times$ greater during a drought year than during a normal flow year in the USA (Canton et al. 1984).

Proportional changes within assemblages are not necessarily consistent, but the total biomass of benthic invertebrates usually is reduced during low-flow events (Walters and Post 2011) and may be linked with the reduced breakdown of BOM. For example, leaf breakdown by shredders over a 6-wk period became significantly lower as experimental drought stress increased (Leberfinger et al. 2010), a result suggesting that low flows reduce energy input to streams despite increased organic matter retention. Indeed, increased duration and magnitude of lowflow events decreases leaf-litter breakdown and microbial conditioning of $\mathrm{BOM}$ and leads to a reduction in allochthonous $C$ entering stream food webs during low flows (Ylla et al. 2010). Assessments of $C$ respiration also show that increased frequency of low-flow events reduces consumer production (Acuña 2010). 
The distance travelled by and biomass of suspended fine particulate organic matter (FPOM) decreases as a function of stream-flow magnitude and velocity (Jones and Smock 1991). Reduced longitudinal delivery of FPOM has been attributed to shortto-medium-term variability in the density and occurrence of filter-feeding macroinvertebrates in drift. In flow-diversion experiments representative of lowflow water abstraction in Canada and New Zealand, filter-feeding macroinvertebrates increased significantly immediately after rapid drawdown, then returned to predisturbance levels after a period of $3 \mathrm{~d}$ to 2 mo (James et al. 2008b, Death et al. 2009). Low flows also reduce the densities and distances traveled by drifting macroinvertebrates as a whole, although short-term increases in drift may occur as dispersal increases. In upland streams in the USA, average drift rates and densities decreased $\sim 82$ and $\sim 92 \%$, respectively, as summer discharge decreased $\sim 88 \%$ over a 2 -mo period (Sotiropoulos et al. 2006).

Reduced total biomass and distance traveled by drifting macroinvertebrates during low flows has significant consequences for predatory consumers (see also the discussion on trophic cascades in Principle 1 above). Two important consequences of reduced availability of food resources are limited individual growth rates and limited population production (biomass). Under low flows, net energy intake by drift-feeding fish declines as a consequence of reduced densities of drifting prey (Closs 1994, Hayes et al. 2007). Reduced energy intake by fish during low flows causes reduced individual and population-level growth. For example, growth of rainbow trout was $8.5 \times$ greater in control reaches than in experimental reaches that experienced a 75 to $80 \%$ reduction in flow over 6 wk (Harvey et al. 2006). Significant positive relationships between stream discharge and both individual growth rates and population size have been demonstrated in experimental flow diversions resulting in gradients of low flow (Blanchet et al. 2008, Walters and Post 2008, Teichert et al. 2010). Reduced discharges are associated consistently with declines in estuarine fishery production across the globe (Drinkwater and Frank 1994). These reductions may be caused by reduced delivery of terrestrial- or river-derived energy sources for higher trophic levels (Loneragan and Bunn 1999). Densities of important species in commercial and recreational fisheries can be positively associated with freshwater discharges into estuaries. As discharge decreases, so does fish density (Staunton-Smith et al. 2004, Vorwerk et al. 2009).

Lateral connections.- - Loss of hydrological connectivity because of low flow reduces lateral energy transfer between river channels and riparian and floodplain zones (Baldwin and Mitchell 2000). Reduced lateral connections in intermittent streams can contribute to changes in the dominant sources of energy (autochthonous vs allochthonous) fuelling aquatic food webs. In many cases, production by autotrophic sources is high or increases because of the increasing disconnection between the floodplain and channel zones (Bunn et al. 2003, Preiner et al. 2008, but see Reid et al. 2008), and autotrophs may become an important source of organic $C$ for higher trophic levels (Bunn et al. 2003, Leigh et al. 2010a, cf. Reid et al. 2012). Fish stranding, death, and the release of nutrients on floodplains during the hydrological disconnection phase of a highly intermittent river in arid zone Australia subsequently fuelled in-channel benthic algal production after hydrological reconnection of the floodplain and channel network (Burford et al. 2008). However, these patterns are highly variable and depend on seasonal, spatial, and local habitat factors (e.g., Dekar et al. 2009).

Reduced production within aquatic ecosystems as a consequence of low (or reduced) flow (see longitudinal connections) also has consequences for production of riparian and terrestrial ecosystems and biota. For example, water diversion in the Murray-Darling Basin, Australia, has reduced the volume of water reaching the Lowbidgee floodplain by up to $60 \%$ and has contributed to a reduction in the production of aquatic biota- a food source for wetland waterbirds, which have declined in abundance by $90 \%$ (Kingsford and Thomas 1995, 2004). Reduced aquatic invertebrate biomass during low flows also controls the biomass and distribution of riparian consumers (e.g., predatory spiders; Greenwood and McIntosh 2010).

Vertical connections. - Connections between benthic substrate, ground water, and surface waters control vertical nutrient exchange (Boulton 2007) and provide a mechanism by which surface-water invertebrates can take refuge in hyporheic sediments during times of low-flow stress (Cooling and Boulton 1993), although use of the hyporheic zone to avoid lowflow stress is not universal across all river types or circumstances (e.g., Wood et al. 2010). Microbial activity in benthic substrates also is positively associated with groundwater-surface water exchange (Battin 2000). Increased deposition and retention of and clogging of substrate by fine sediments during low-flow events (see Principle 1 above) restrict nutrient transport from benthic substrates, groundwater, and hyporheic zones to surface waters and food webs. In conjunction, groundwater levels decrease during prolonged low flow (Dahm et al. 2003). For example, low flows typically reduce inputs and 
availability of dissolved organic C (DOC) from benthic zones, and reduced flow restricts DOC (i.e., energy) inputs from ground water and terrestrial zones to streams (Dahm et al. 2003). Increased sedimentation decreases benthic macroinvertebrate biomass and increases dominance by burrowing taxa. This shift leads to the disappearance of food sources into the substrate and is associated with a reduction in individual growth and population density of juvenile salmonids (Suttle et al. 2004).

Principle 4: Low flow restricts connectivity and diversity of habitat, increases the importance of refugia, and drives multiscale patterns in biotic diversity.

Low flow increases disconnection between river reaches and between river and floodplain habitats, and thereby restricts movement and dispersal among habitat patches, river reaches, rivers, and estuaries. Dispersal and refuge habitats are necessary for persistence of metapopulations in regions vulnerable to prolonged low flows. Dispersal of migratory fish, such as Australian bass (Maquaria novemaculeata), is restricted by contraction of riffles during low flows into shallow, (temporarily) fast-velocity zones that exceed swimming abilities (Reinfelds et al. 2010). However, low flows trigger many aquatic biota to disperse and seek refuge (Magoulick and Kobza 2003), despite the physical restrictions imposed by their decreasing aquatic habitat. Therefore, the persistence of biota in rivers where low flows are natural phenomena depends on the ability of species to access refugia and on the viability of source populations. For example, during riffle dewatering caused by experimental low flows, upland bullies (Gobiomorphus breviceps) moved downstream to flowing run habitats, whereas Canterbury galaxias (Galaxias vulgaris) burrowed into coarse substrata and were susceptible to surface stranding (Davey et al. 2006). Low-flow water abstraction in Austrian streams can increase habitat fragmentation and restrict movement contributing to reduced persistence of bullhead (Cottus gobio) (Fischer and Kummer 2000). Rate of flow recession may determine the ability of individuals to move to refugia. For example, slow rates of flow recession may allow individuals to reach refugia successfully but rapid rates may restrict dispersal opportunities. Both empirical and experimental studies indicate that rapid rate of change in flow explains the lack of migration by benthos into the hyporheic zone (Stubbington 2012). Thus, low flows can simultaneously stimulate and restrict dispersal of biota.

Refugia provide habitat for biota to persist and maintain source populations during disturbance, which includes low flows and drought (Sedell et al. 1990, Magoulick and Kobza 2003). Access to multiple refugia increases resilience of metapopulations to disturbances and increases in importance as duration of low flow increases (Labbe and Fausch 2000). Use of and movement to refugia by biota is linked to the duration of low-flow stress in aquatic ecosystems. For example, experimental flow diversions that mimicked water abstraction in New Zealand rivers over a 1mo period resulted in no detectable impact on macroinvertebrate assemblages because local and multiple refuge habitats (e.g., pools, hyporheic zones) remained available (James et al. 2008a). However, use of the hyporheic zone by macroinvertebrates as refugia during supraseasonal low flows indicates that use of refugia increases with increasing low-flow stress as surface habitats dry (Wood et al. 2010). During stream drying in an intermittent river in the USA, freshwater crayfish (Orconectes williamsi and Orconectes meeki meeki) used hyporheic substrates as refugia rather than migrating downstream to surface-water refugia (DiStefano et al. 2009), a result indicating that species capable of aestivation can persist in habitats where low flows occur. Refuge size also can affect the persistence of local populations and broader metapopulations. For example, local extinctions of the endangered tidewater goby (Eucyclogobius newberryi) decreased with increasing refugia size during multiyear drought in coastal wetlands in the USA (Lafferty et al. 1999). Species-specific differences in dispersal capabilities can assist in predicting which biota are most susceptible to the loss of refugia during low flows (Crook et al. 2010). Even after flow resumes, loss of refugia can have long-term impacts on biotic composition and species persistence (Rayner et al. 2009).

Dispersal traits and the availability of refugia have broad implications for multiscale patterns in biotic diversity during and after low-flow events (Chester and Robson 2011). Flow-mediated connection of habitats affects spatial variation in composition of biota in rivers (i.e., $\beta$ diversity; Thomaz et al. 2007, Larned et al. 2010). $\beta$ diversity is broadly defined as the variation in species composition among samples (e.g., habitats or reaches) in a given area (e.g., a river basin) (Anderson et al. 2011). $\beta$ diversity is predicted to peak during intermediate connectivity and to decline with further increases or decreases in connectivity (e.g., Leigh and Sheldon 2009, Larned et al. 2010). When compared to average flow conditions, prolonged low flows usually increase $\beta$ diversity, primarily because of differential losses of sensitive taxa, effects of local driving forces (Thomaz et al. 2007), and decreased connectivity. For example, 
decline of sensitive taxa as flow and water receded increased spatial variation in macroinvertebrate assemblage composition and richness across intermittent streams in the USA (Bonada et al. 2006), Australia (Lind et al. 2006), and Brazil (Macedo-Sores et al. 2010). As sensitive species are lost from assemblages during prolonged low-flow events, separate refugia support increasingly distinct assemblages until only generalist, tolerant species persist and the assemblages become homogenous across refugia (Magalhães et al. 2002, Sheldon et al. 2010).

\section{Human-Induced Alterations to Low-Flow Hydrology}

Natural and anthropogenic disturbances can alter the ecologically relevant attributes of low-flow hydrology. The specific hydrological change depends on the nature of the disturbance and antecedent low-flow regime (Table 1). Patterns in low-flow hydrology are particularly sensitive to changes in climate patterns, land use in the surrounding catchment, and human impacts on stream flow (Smakhtin 2001). These factors, in turn, influence aquatic and terrestrial ecosystems by altering the mechanistic relationships that determine patterns and processes within and among ecosystems. With the 4 principles outlined above in mind, we discuss 6 major human-induced threats to low-flow hydrology and how they act upon the ecologically relevant hydrological attributes of low flow identified above.

\section{Flow regulation}

Research on the hydrological and ecological consequences of flow regulation has generally been focused on the effects of floods and restoring high-flow events (Maheshwari et al. 1995, Poff et al. 1997). However, flow regulation also alters the low-flow hydrology of rivers. Many flow-regulation schemes are used to provide water for irrigation and agriculture during dry periods and times of peak demand. Flows are often artificially elevated above natural conditions during these times and natural periods of low flow are eliminated to create 'anti-droughts' (McMahon and Finlayson 2003, Bunn et al. 2006). Seasonality of flow is often altered despite little change in the total annual discharge, and, in some cases, is reversed entirely (Humphries et al. 2008) such that the lowflow period no longer co-occurs with the usual seasonal cues for biotic responses and ecosystem processes.

Effects of flow regulation on low-flow hydrology vary across rivers and regions. For instance, flow regulation in the Murray River, Australia, has changed large floods only slightly (recurrence time of $20 \mathrm{y}$ ), but low-flow magnitudes have increased relative to natural (unregulated) conditions (Maheshwari et al. 1995). In contrast, water-resource-development models for tropical Australia, which included flow regulation, predicted reductions in minimum and average daily flows across multiple river basins (Leigh and Sheldon 2008). In general, flow regulation reduces the severity (i.e., increases the magnitude and decreases the frequency and duration) of low-flow events (McMahon and Finlayson 2003).

\section{Surface-water abstraction}

Abstraction of surface water from unregulated rivers produces artificial drought (Boulton 2003), with reduced magnitude and increasing frequency and duration of low-flow events. Floodplain harvesting of water in dryland rivers is expected to increase the duration of low-flow periods (Bunn et al. 2006), and upstream water withdrawals are likely to reduce downstream flow magnitudes and the longitudinal distance travelled by water downstream, resulting in wetland drying and disrupted cycles of biotic production (Leigh et al. 2010b). Surface-water abstraction in the USA, Spain, and Australia has increased the frequency of low flows, particularly during naturally drier periods (Deitch et al. 2009b, Finn et al. 2009, Benejam et al. 2010). In some cases, surfacewater abstraction from small streams to protect vineyard crops during periods of extreme air temperatures (e.g., frost) has caused abrupt changes to flows, with up to a $97 \%$ decline in discharge lasting almost $5 \mathrm{~d}$ (Deitch et al. 2009a). Under a hypothetical scenario of water abstraction and impoundment, flow regimes of rivers in tropical Australia that have comparatively low-flow magnitudes (i.e., low and no flows are natural features of the hydrographs of these rivers) showed an increase in interannual flow variability and intensification of the extremes of magnitude in their flow regimes (e.g., the lowest flow magnitudes became even lower) (Leigh and Sheldon 2008). Therefore, surface abstraction may change the amount of natural variation in the flow regimes of rivers characterized by low flows.

\section{Interbasin transfers}

Interbasin transfers affect the hydrology of source and receiving rivers. The consequences of interbasin transfers for source rivers are similar to those of surface-water abstraction (see Surface-water abstraction above and Table 1), whereas consequences for receiving rivers generally are elevated discharge and reduced frequency and duration of natural low flows (anti-drought; see Flow regulation above). Reduced 


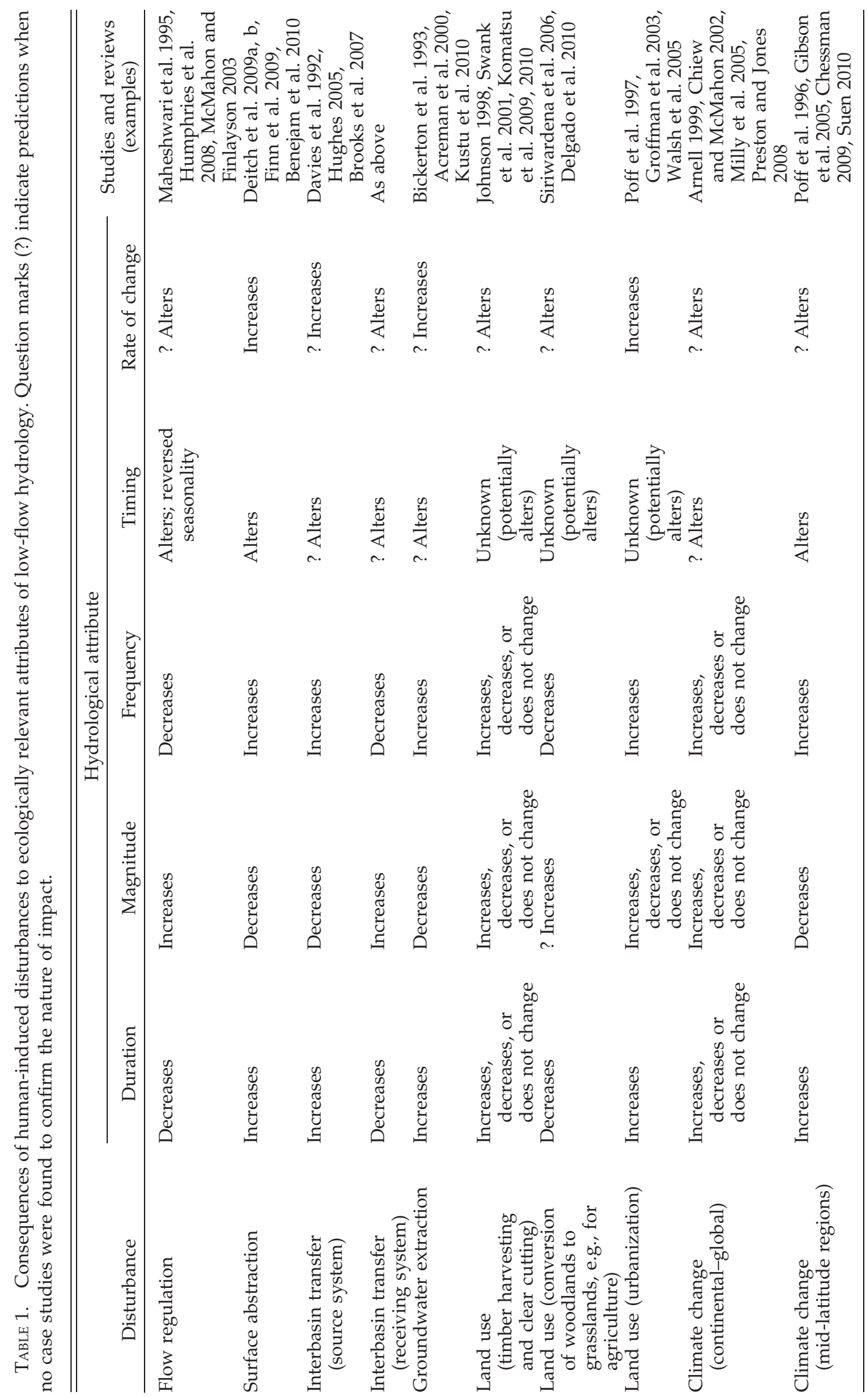


flow variability occurs for both source and receiving rivers, and this alteration is particularly significant in ephemeral rivers (Hughes 2005). The Snowy Mountain Scheme in Australia is one example of an interbasin transfer (Davies et al. 1992). This scheme diverted $96 \%$ of total annual flow from the Snowy River in coastal, southeast Australia, to the more inland River Murray and Murrumbidgee Irrigation Area. The results were increased duration and frequency of low flow and floods of smaller magnitude and reduced frequency in the Snowy River (Brooks et al. 2007). In South Africa, an interbasin transfer increased the flow magnitude in the receiving river by 830 to $4500 \%$ in 1994, depending on seasonal demands, and the artificially elevated discharges in summer were equal to the naturally high discharges in winter (Snaddon and Davies 1998).

\section{Groundwater extraction}

Worldwide, groundwater extraction has increased dramatically since the mid-1900s (Acreman et al. 2000). Many surface-flowing rivers are tightly linked with groundwater via the contribution of groundwater to base flow (Boulton and Hancock 2006), and changes to groundwater aquifers affect low-flow hydrology in such systems. The hydrological consequences of groundwater extraction on surface low flows are often similar to those of surface water abstraction (Table 1). Groundwater extraction can severely affect natural groundwater levels and aquifer recharge rates and has the potential to decrease the magnitude and increase the frequency and duration of low-flow events in surface-flowing rivers, reduce base flows, and shorten persistence of refugial waterholes. Groundwater extraction has been associated with increased duration and frequency of low flows in the UK and USA (Acreman et al. 2000, Bickerton et al. 1993, Kustu et al. 2010). Furthermore, conservative future scenarios for groundwater extraction in the Great Plains, USA, predict that groundwater extraction will eliminate $43 \%$ of refuge pools and will reduce the remaining pools in discrete reaches, thereby eliminating longitudinal surface connectivity, which may have severe impacts on biota unable to cope with stranding and desiccation of surface waters (e.g., fish; Falke et al. 2011).

\section{Land use}

Urbanization, agriculture, and forestry are the primary drivers of flow-regime change in many rivers (Poff et al. 1997) and have direct effects on low-flow hydrology. These effects can be inconsistent and are likely to depend on the specific nature of the landuse change (Table 1). In the context of low flows, urbanization can cause reduced baseflow conditions by decreasing infiltration as a consequence of increased impervious surface cover in catchments. However, changes to the magnitude of base flow are not consistent across all urban systems (Poff et al. 1997, Walsh et al. 2005). Instead, urban streams typically experience greater flashiness of flow, and stormwater often is piped directly into streams such that the rate of change from low to high flow (and vice versa) is greater than that of the natural flow regime (Walsh et al. 2005).

Low-flow hydrology also is affected by anthropogenic conversion of plant cover for agriculture, plantations, and forestry and specific activities associated with these land uses (Johnson 1998). For example, Siriwardena et al. (2006) reported a $40 \%$ increase in annual runoff (after accounting for changes in rainfall) associated with the conversion of Acacia harpophylla woodlands to grasslands for cropping and cattle grazing in the Comet River of central Queensland, Australia. In Pyrenean headwater catchments in northeastern Spain, low flows have decreased in magnitude as land use has shifted from agriculture to natural shrub and forest cover (Delgado et al. 2010). However, conversion of coniferous forest plantations to broadleaf forests in Japan resulted in no change to the frequency or magnitude of low flows (Komatsu et al. 2009). Following large-scale commercial timber harvesting in the Appalachians of North Carolina, USA, river discharge increased by $28 \%$ in the first year, then declined constantly over the next 4 y before returning to preharvest conditions (Swank et al. 2001). Deforestation (forest clear-cutting) increased the severity of low-flow conditions in 5 catchments in Japan, but changes were minor when compared to the consequences and management of 45 dams throughout the country (Komatsu et al. 2010).

\section{Climate change and variability}

At the catchment-scale, elevated temperatures and decreased rainfall will result in decreased average runoff, thereby decreasing magnitude and increasing the frequency and duration of low-flow periods (Poff et al. 1996). Increased frequency and duration of low flows have occurred or are predicted to occur under climate change scenarios in tropical and temperate regions (Chiew and McMahon 2002, Gibson et al. 2005, Suen 2010). Temperate regions of New Zealand's eastern South Island are experiencing more extreme hydrology under recent climate variability (McKerchar and Henderson 2003), and in New South Wales, Australia, mean rainfall and river flows have 
declined and temperatures increased over a recent 13-y period (1994 to 2007; Chessman 2009). Where high levels of consumptive water use exist, decreased water availability caused by climate change is likely to have a disproportionate impact on the environmental share of surface water, such that low flows are likely to decrease in magnitude and increase in duration and frequency.

Climate change is also predicted to alter seasonality of flow, particularly in snowmelt-dominated catchments. For example, climate change in Europe is predicted to reduce or eliminate winter snow, which usually results in spring run-off during snow melt. Spring flows will be replaced by higher winter flows as rainfall replaces snowfall (Arnell and Reynard 1996). Indeed, much of the northern region of the northern hemisphere is predicted to experience greater runoff in the $21^{\text {st }}$ century (Milly et al. 2005), and changes to snowfall are predicted to be detectable on a decadal basis because of strong interannual variability (Arnell 1999). Reduced snowfall also is predicted in other temperate regions, such as southern Australia (Hughes 2003).

Climate-change effects are likely to affect freshwater biodiversity via direct changes to river hydrology (including low-flow hydrology) and other pathways. For example, projected changes to the Australian climate are associated with increased variability and severity of extreme hydrological events (i.e., floods and droughts) and with higher water temperatures and loss of lowland freshwater habitats from saline intrusion as a result of rising sea level and more extreme storm surges (Hughes 2003). Global analysis of future climatechange scenarios indicates that in rivers with predicted reduction in flow, up to $75 \%$ of local fish biodiversity is at risk of extinction by 2070 because of the direct effects of climate change and increased water demand by humans (Xenopoulos et al. 2005).

\section{Synthesis: Mechanistic Links Between Low Flow and Aquatic Ecosystems, the Complexity of Low \\ Flow as a Disturbance, and Applications for Research and Management}

We have proposed 4 principles that outline the mechanistic links between low flows and processes and patterns in riverine ecosystems. These principles explain and may be observed as ecological responses to hydrological attributes of low flow. First, low flows control the extent of physical aquatic habitat and, thereby, influence the composition and diversity of biota, trophic structure, and carrying capacity. Second, low flows mediate changes in habitat conditions and water quality, which in turn drive patterns in the distribution and recruitment of biota. Third, low flows affect sources and exchange of energy in riverine ecosystems and, thus, affect ecosystem production and biotic composition. Fourth, low flows restrict connectivity and diversity of habitat, increase the importance of refugia, and drive multiscale patterns in biotic diversity.

These principles do not operate in isolation (Fig. 2), and many ecological effects of low flows are likely to occur simultaneously, potentially resulting in similar or complex effects (e.g., synergisms or antagonisms; Folt et al. 1999). Therefore, the links between low-flow hydrology and riverine ecosystems and biodiversity cannot be oversimplified and, to some extent, are difficult to generalize. Moreover, the nature of ecological responses to low-flow hydrology depends on the hierarchical nature of the flow regime and river habitats (sensu Frissell et al. 1986, Biggs et al. 2005). Many of the ecological responses to individual lowflow events appear to occur only after a particular magnitude, duration, or frequency of events has been reached. Therefore, other than changes in river flow, few early warning indicators of ecological stress from low flows and their alteration are likely to exist. To define ecologically relevant and critical shifts in lowflow hydrology, the nature and breadth of ecological responses must be identified.

Low flows can exacerbate or mask the effects of other environmental stressors on aquatic ecosystems. Human impacts on river ecosystems, such as sedimentation, increased nutrients, poor water quality, landuse change, and water extraction, often have the strongest influence during low flows. For example, effects of sedimentation on macroinvertebrate assemblages in experimental streams in New Zealand were greater in flow conditions mimicking water abstraction than natural flows (Matthaei et al. 2010). Human impacts on rivers (e.g., poor water quality, salinity) can compound the effects of low flows in rivers by creating conditions that exceed the tolerance thresholds of many biota (Lind et al. 2006). Low flow also exacerbates the effects of barriers to movement of stream biota (Burford et al. 2009), and protracted lowflow conditions can override efforts to reduce or predict the impacts of anthropogenic disturbance. For example, prolonged periods of below-average rainfall (and hence, stream flow) have been associated with the limited response of fish to in-stream habitat restoration (Bond and Lake 2005, Howson et al. 2009) and can eliminate the predicted effects of urbanization on estuarine nutrients and water quality (Elsdon et al. 2009). Such complexities create challenges and opportunities to understand the effects of low flows and their alteration on aquatic ecosystems. 
Low flows have been used as natural phenomena to study and understand ecological responses to disturbances (often in terms of resistance and resilience; Reice et al. 1990, Lake 2000, Chester and Robson 2011). However, low flows are a complex form of disturbance in aquatic ecosystems. Low flows can be a severe disturbance (e.g., drought), but in some contexts they can constitute an absence of disturbance (e.g., loss of large floods from the flow regime). Rates of silt and sediment deposition increase and cover and richness of macrophytes and benthic algae decrease with increasing frequency of high-flow disturbances (Biggs 1996, Riis and Biggs 2003, Riis et al. 2008), and strong trophic links can form in the absence of floods in streams (Wootton et al. 1996). Therefore, some ecological responses to low-flow hydrology may be caused as much by the absence of flood disturbance as by the occurrence of stable low flows.

We have synthesized the findings of a broad range of studies to improve our understanding of low-flow ecohydrology and the mechanisms by which low flows and their alteration may affect riverine ecosystems. Identifying and quantifying causal mechanisms is critical to identifying the effects of stressors so that the most appropriate predictors and response variables can be defined and sampled (Downes 2010). However, many of the authors of the studies reviewed in our synthesis did not specifically test causal hypotheses about the ecological consequences of low flow, but rather, used exploratory or descriptive approaches to infer ecological responses to low flow. Studies in which causal hypotheses are specified and tested are particularly informative (e.g., Osmundson et al. 2002, Suttle et al. 2004) because they can be used to determine whether a particular stressor mediated by flow is causing a change in ecosystem structure and function. Therefore, the mechanistic links described in our synthesis should be used to develop and test hypotheses about ecological responses to low-flow hydrology in a cause-effect framework that will have value for ecohydrological scientists and river flow managers. For example, a fundamental tenet of the Ecological Limits of Hydrologic Alteration (ELOHA) framework (Poff et al. 2010) is to develop mechanistic or process-based relationships between patterns in ecosystem structure or function and variation in the flow regime that can be applied to the development of environmental flow regimes.

Detecting initial ecological effects of low flow is likely to be difficult because the disturbance occurs in the form of a press or ramp (Lake 2003). The ecological mechanisms affected by low flows occur over multiple time scales and, therefore, responses to low-flow disturbances are likely to be delayed (i.e., show lag effects). Ecological research on low flows has tended to be focused on relatively short-term effects of single low-flow events or experimental manipulations, and findings are often inconsistent (Miller et al. 2010). One hypothesis is that ecosystems show no response to low-flow events until a distinct point or "threshold" of duration or magnitude is passed. An alternative theory is that individual lowflow events do not necessarily change the long-term flow regime by which ecosystems are predominantly structured (sensu Biggs et al. 2005). The long-term flow regime acts as a form of biological filter (Bonada et al. 2007), whereby biota that are unable to recover from sustained disturbances do not exist in the regional species pool (Lake et al. 2007). The composition of aquatic biota often responds more obviously to changes in flow regimes as they move from perennial to intermittent flow over (at least) multiple years rather than to single, short-term events (Sponseller et al. 2010, Bogan and Lytle 2011). However, relatively few of the case studies used in our synthesis provided much detail on the antecedent conditions or flow regimes of the rivers in which the effects of individual low-flow events were studied. Instead, many flow regimes were described simply as perennial, intermittent, or temporary. This lack of detail presents difficulties when deciding whether single flow events are within the natural variation of the long-term flow regime and the conditions through which aquatic biota are expected to persist, or whether the events represent a change in the flow regime that would initiate significant ecological responses and a persistent trajectory of change.

The processes and mechanisms by which low flows affect aquatic ecosystems identified in our paper are driven both by the hydrological characteristics of individual flow events (e.g., duration, timing, frequency) and by the context of events within the temporal hierarchy of the long-term low-flow regime. Disentangling the relative importance of these different flow disturbance attributes (described above) is necessary to isolate their individual and interacting ecological effects (sensu Fraterrigo and Rusak 2008). Rules for environmental flows defined at particular flow percentiles or magnitudes that fail to recognize the temporal hierarchy of the low-flow regime will place biota and ecological processes in streams at risk and could contribute to altered trajectories of ecosystem structure and aquatic biodiversity. If threats to low-flow hydrology (e.g., water abstraction from unregulated streams) alter the duration, frequency, and potentially, the timing of low-flow events that are expected to induce an ecological shift, then setting 
only magnitude-based environmental flow rules significantly risks altering ecosystem structure, function, and biodiversity by contributing to potentially undesirable changes in the flow regime. One solution could be to apply more dynamic water extraction rules that account for antecedent flow conditions (Finn et al. 2009) and provide scope to acknowledge the temporal hierarchy of each river's flow regime.

Low flows and drought are useful model phenomena for studying and understanding the effects of disturbance on ecosystems. Such understanding helps scientists to develop ecological theory of disturbance ecology (Death 2010) and to apply it to conservation and restoration actions (Lake et al. 2007) in the context of river flow management and adaptation to human demands and climate variability (Poff et al. 2010). Continued experimental research and ongoing consolidation of ecological information will improve our understanding and ability to predict consequences of low-flow alteration on river, floodplain, and estuarine ecosystems.

\section{Acknowledgements}

This synthesis is based on a scoping study funded by the Australian National Water Commission. Clare Taylor, Richard Davis, and Paul Wettin provided project management and guidance and Mark Kennard, Brad Pusey, and Ben Stewart-Koster contributed to discussions during initial phases of the project. We thank Kate Smolders for valuable comments on a draft of the manuscript, and David B. Arscott, Jeffrey Falke, and an anonymous referee for their suggestions to improve the manuscript.

\section{Literature Cited}

Acreman, M. C., B. Adams, And B. Connorton. 2000. Does groundwater abstraction cause degradation of rivers and wetlands? Water and Environment Journal 14: 200-206.

AcuÑA, V. 2010. Flow regime alteration effects on the organic C dynamics in semiarid stream ecosystems. Hydrobiologia 657:233-242.

Acuña, V., I. Muñoz, A. Giorgi, M. Omella, F. Sabater, and S. SABATER. 2005. Drought and postdrought recovery cycles in an intermittent Mediterranean stream: structural and functional aspects. Journal of the North American Benthological Society 24:919-933.

Alpine, A. E., AND J. E. Cloern. 1992. Trophic interactions and direct physical effects control phytoplankton biomass and production in an estuary. Limnology and Oceanography 37:946-955.

Anderson, M. J., T. O. Crist, J. M. Chase, M. Vellend, B. D. Inouye, A. L. Freestone, N. J. Sanders, H. V. Cornell, L. S. Comita, K. F. Davies, S. P. Harrison, N. J. B. Kraft,
J. C. Stegen, and N. G. Swenson. 2011. Navigating the multiple meanings of $\beta$ diversity: a roadmap for the practicing ecologist. Ecology Letters 14:19-28.

ArNell, N. W. 1999. The effect of climate change on hydrological regimes in Europe: a continental perspective. Global Environmental Change 9:5-23.

Arnell, N. W., And N. S. Reynard. 1996. The effects of climate change due to global warming on river flows in Great Britain. Journal of Hydrology 183:397-424.

Arscott, D. B., S. Larned, M. R. Scarsbrook, and P. Lambert. 2010. Aquatic invertebrate community structure along an intermittence gradient: Selwyn River, New Zealand. Journal of the North American Benthological Society 29: 530-545.

Arthington, A. H., and S. R. Balcombe. 2011. Extreme flow variability and the 'boom and bust' ecology of fish in arid-zone floodplain rivers: a case history with implications for environmental flows, conservation and management. Ecohydrology 4:708-720.

Arthington, A. H., S. E. Bunn, N. L. Poff, and R. J. Naiman. 2006. The challenge of providing environmental flow rules to sustain river ecosystems. Ecological Applications 16:1311-1318.

Baldwin, D. S., AND A. M. Mitchell. 2000. The effects of drying and re-flooding on the sediment and soil nutrient dynamics of lowland river-floodplain systems: a synthesis. Regulated Rivers: Research and Management 16:457-467.

Baldwin, D. S., J. Wilson, H. Gigney, And A. Boulding. 2010. Influence of extreme drawdown on water quality downstream of a large water storage reservoir. River Research and Applications 26:194-206.

Baran, P., M. Delacoste, F. Dauba, J. M. Lascaux, A. Belaud, AND S. LEK. 1995. Effects of reduced flow on brown trout (Salmo trutta L.) populations downstream dams in French Pyrenees. Regulated Rivers: Research and Management 10:347-361.

BAtTIN, T. J. 2000. Hydrodynamics is a major determinant of streambed biofilm activity: from the sediment to the reach scale. Limnology and Oceanography 45:1308-1319.

Bêche, L. A., P. G. Connors, V. H. Resh, And A. M. Merenlender. 2009. Resilience of fishes and invertebrates to prolonged drought in two California streams. Ecography 32:778-788.

Benejam, L., P. L. Angermeier, A. Munné, and E. GarcíaBERTHOU. 2010. Assessing effects of water abstraction on fish assemblages in Mediterranean streams. Freshwater Biology 55:628-642.

BerKman, H. E., AND C. F. RABENI. 1987. Effect of siltation on stream fish communities. Environmental Biology of Fishes 18:285-294.

Bickerton, M., G. Petts, P. Armitage, and E. Castella. 1993. Assessing the ecological effects of groundwater abstraction on chalk streams: three examples from eastern England. Regulated Rivers: Research and Management 8:121-134.

Biggs, B. J. F. 1996. Hydraulic habitat of plants in streams. Regulated Rivers: Research and Management 12: 131-144. 
Biggs, B. J. F., V. L. Nikora, And T. H. SNelder. 2005. Linking scales of flow variability to lotic ecosystem structure and function. River Research and Applications 21:283-298.

Biggs, B. J. F., AND S. STOKSETH. 1996. Hydraulic habitat suitability for periphyton in rivers. Regulated Rivers: Research and Management 12:251-261.

Bishop, K. A., AND J. D. Bell. 1978. Observations of the fish fauna below Tallowa Dam (Shoalhaven River, New South Wales) during river flow stoppages. Australian Journal of Marine and Freshwater Research 29:543-549.

Blanchet, S., G. Loot, And J. J. Dodson. 2008. Competition, predation and flow rate as mediators of direct and indirect effects in a stream food chain. Oecologia (Berlin) 157:93-104.

Bogan, M. T., AND D. A. LytLe. 2011. Severe drought drives novel community trajectories in desert stream pools. Freshwater Biology 56:2070-2081.

Bonada, N., M. Rieradevall, and N. Prat. 2007. Macroinvertebrate community structure and biological traits related to flow permanence in a Mediterranean river network. Hydrobiologia 589:91-106.

Bonada, N., M. Rieradevall, N. Prat, and V. H. Resh. 2006. Benthic macroinvertebrate assemblages and microhabitat connectivity in Mediterranean-climate streams in northern California. Journal of the North American Benthological Society 25:32-43.

BOND, N. R., AND P. S. LAKE. 2005. Ecological restoration and large-scale ecological disturbance: the effects of drought on the response by fish to a habitat restoration experiment. Restoration Ecology 13:39-48.

Boulton, A. J. 2003. Parallels and contrasts in the effect of drought on stream macroinvertebrate assemblages. Freshwater Biology 48:1173-1185.

Boulton, A. J. 2007. Hyporheic rehabilitation in rivers: restoring vertical connectivity. Freshwater Biology 52: 632-650.

Boulton, A. J., And P. J. HAnCock. 2006. Rivers as groundwater-dependent ecosystems: a review of degrees of dependency, riverine processes and management implications. Australian Journal of Botany 54: 133-144.

Boulton, A. J., And P. S. Lake. 1990. The ecology of two intermittent streams in Victoria, Australia. I. Multivariate analyses of physicochemical features. Freshwater Biology 24:123-141.

Boulton, A. J., AND P. S. LAKe. 1992a. Benthic organic matter and detritivorous macroinvertebrates in two intermittent streams in south-eastern Australia. Hydrobiologia 241:107-118.

Boulton, A. J., And P. S. LaKe. 1992b. The ecology of two intermittent streams in Victoria, Australia. III. Temporal changes in faunal composition. Freshwater Biology 27: 123-138.

Boulton, A. J., AND P. S. LAKE. 2008. Effects of drought on stream insects and its ecological consequences. Pages 81-102 in J. Lancaster and R. Briers (editors). Aquatic insects: challenges to populations. CABI Publishing, Wallingford, UK.
Bowling, L. C., AND P. D. BAKER. 1996. Major cyanobacterial bloom in the Barwon-Darling River, Australia, in 1991, and underlying limnological conditions. Marine and Freshwater Research 47:643-657.

BRADFORD, M. J. 1997. An experimental study of stranding of juvenile salmonids on gravel bars and in sidechannels during rapid flow decreases. Regulated Rivers: Research and Management 13:395-401.

BROOKS, A., M. Russell, AND R. BEvitT. 2007. Response of aquatic macroinvertebrates to the first environmental flow regime in the Snowy River. New South Wales Department of Water and Energy, Sydney, Australia. (Available from: http:// www.water.nsw.gov.au/Water-management/Monitoring/ Snowy-River/Snowy-River/default.aspx)

Brooks, A. J., B. C. Chessman, And T. Haeusler. 2011. Macroinvertebrate traits distinguish unregulated rivers subject to water abstraction. Journal of the North American Benthological Society 30:419-435.

BRoOKs, A. J., T. HAeusler, I. ReinfeldS, AND S. Williams. 2005. Hydraulic microhabitats and the distribution of macroinvertebrate assemblages in riffles. Freshwater Biology 50:331-344.

Bunn, S. E., And A. H. Arthington. 2002. Basic principles and ecological consequences of altered flow regimes for aquatic biodiversity. Environmental Management 30: 492-507.

Bunn, S. E., P. M. Davies, And M. Winning. 2003. Sources of organic carbon supporting the food web of an arid zone floodplain river. Freshwater Biology 48:619-635.

Bunn, S. E., M. C. Thoms, S. K. Hamilton, and S. J. Capon. 2006. Flow variability in dryland rivers: boom, bust and the bits in between. River Research and Applications 22: 179-186.

Burford, D. D., T. E. McMahon, J. E. CAhoOn, and M. Blank. 2009. Assessment of trout passage through culverts in a large Montana drainage during summer low flow. North American Journal of Fisheries Management 29: 739-752.

Burford, M. A., A. J. Cook, C. S. Fellows, S. R. Balcombe, And S. E. BunN. 2008. Sources of carbon fuelling production in an arid floodplain river. Marine and Freshwater Research 59:224-234.

Burns, A., AND K. F. WALKER. 2000. Effects of water level regulation on algal biofilms in the River Murray, South Australia. Regulated Rivers: Research and Management 16:433-444.

Canton, S. P., L. D. Cline, R. A. Short, and J. V. Ward. 1984. The macroinvertebrates and fish of a Colorado stream during a period of fluctuating discharge. Freshwater Biology 14:311-316.

Castella, E., M. Bickerton, P. D. Armitage, and G. E. Petts. 1995. The effects of water abstractions on invertebrate communities in U.K. streams. Hydrobiologia 308: 167-182.

Chakona, A., C. Phiri, C. Magadza, and L. Brendonck. 2008. The influence of habitat structure and flow permanence on macroinvertebrate assemblages in temporary rivers in northwestern Zimbabwe. Hydrobiologia 607:199-209. 
Chessman, B. C. 2009. Climatic changes and 13-year trends in stream macroinvertebrate assemblages in New South Wales, Australia. Global Change Biology 15:2791-2802.

Chessman, B. C., And D. P. Robinson. 1987. Some effects of the 1982-83 drought on water quality and macroinvertebrate fauna in the lower La Trobe River, Victoria. Marine and Freshwater Research 38:289-299.

Chester, E. T., And B. J. Robson. 2011. Drought refuges, spatial scale and recolonisation by invertebrates in nonperennial streams. Freshwater Biology 56:2094-2104.

Chiew, F. H. S., And T. A. McMahon. 2002. Modelling the impacts of climate change on Australian streamflow. Hydrological Processes 16:1235-1245.

Closs, G. P. 1994. Feeding of Galaxias olidus (Günther) (Pisces: Galaxiidae) in an intermittent Australian stream. Australian Journal of Marine and Freshwater Research 45:227-232.

Closs, G. P., And P. S. LaKe. 1994. Spatial and temporal variation in the structure of an intermittent-stream food web. Ecological Monographs 64:1-21.

Closs, G. P., AND P. S. LAKE. 1996. Drought, differential mortality and the coexistence of a native and an introduced fish species in a south east Australian intermittent stream. Environmental Biology of Fishes 47: 17-26.

Connor, W. P., H. L. Burge, J. R. Yearsley, and T. C. Bjornn. 2003. Influence of flow and temperature on survival of wild subyearling fall chinook salmon in the Snake River. North American Journal of Fisheries Management 23: 362-375.

CoOling, M., AND A. Boulton. 1993. Aspects of the hyporheic zone below the terminus of a South Australian aridzone stream. Marine and Freshwater Research 44: 411-426.

Cotton, J. A., G. Wharton, J. A. B. Bass, C. M. Heppell, And R. S. Wotton. 2006. The effects of seasonal changes to in-stream vegetation cover on patterns of flow and accumulation of sediment. Geomorphology 77:320-334.

Cowx, I. G., W. O. Young, and J. M. Hellawell. 1984. The influence of drought on fish and invertebrate populations of an upland stream in Wales. Freshwater Biology 14:165-177.

Crook, D. A., P. Reich, N. R. Bond, D. McMaster, J. D. KoeHn, And P. S. LAKe. 2010. Using biological information to support proactive strategies for managing freshwater fish during drought. Marine and Freshwater Research 61:379-387.

Dahm, C. N., M. A. Baker, D. I. Moore, and J. R. Thibault. 2003. Coupled biogeochemical and hydrological responses of streams and rivers to drought. Freshwater Biology 48:1219-1231.

Dare, M. R., W. A. Hubert, and K. G. Gerow. 2002. Changes in habitat availability and habitat use and movements by two trout species in response to declining discharge in a regulated river during winter. North American Journal of Fisheries Management 22:917-928.

DAtry, T. 2012. Benthic and hyporheic invertebrate assemblages along a flow intermittence gradient: effects of duration of dry events. Freshwater Biology 57:563-574.
Davey, A. J. H., AND D. J. Kelly. 2007. Fish community responses to drying disturbances in an intermittent stream: a landscape perspective. Freshwater Biology 52: 1719-1733.

Davey, A. J. H., D. J. Kelly, and B. J. F. Biggs. 2006. Refugeuse strategies of stream fishes in response to extreme low flows. Journal of Fish Biology 69:1047-1059.

Davies, B. R., M. Thoms, and M. Meador. 1992. An assessment of the ecological impacts of inter-basin water transfers, and their threats to river basin integrity and conservation. Aquatic Conservation: Marine and Freshwater Ecosystems 2:325-349.

DeAn, T. L., AND J. Richardson. 1999. Responses of seven species of native freshwater fish and a shrimp to low levels of dissolved oxygen. New Zealand Journal of Marine and Freshwater Research 33:99-106.

DeAth, R. G. 2010. Disturbance and riverine benthic communities: what has it contributed to general ecological theory? River Research and Applications 26: 15-25.

Death, R. G., Z. S. Dewson, and A. B. W. James. 2009. Is structure or function a better measure of the effects of water abstraction on ecosystem integrity? Freshwater Biology 54:2037-2050.

Deitch, M. J., G. M. Kondolf, And A. M. Merenlender. 2009a. Hydrologic impacts of small-scale instream diversions for frost and heat protection in the California wine country. River Research and Applications 25:118-134.

Deitch, M. J., G. M. Kondolf, And A. M. Merenlender. 2009 b. Surface water balance to evaluate the hydrological impacts of small instream diversions and application to the Russian River basin, California, USA. Aquatic Conservation: Marine and Freshwater Ecosystems 19: 274-284.

Dekar, M. P., AND D. D. Magoulick. 2007. Factors affecting fish assemblage structure during seasonal stream drying. Ecology of Freshwater Fish 16:335-342.

Dekar, M., D. Magoulick, and G. Huxel. 2009. Shifts in the trophic base of intermittent stream food webs. Hydrobiologia 635:263-277.

Delgado, J., P. Llorens, G. Nord, I. R. Calder, and F. GALLART. 2010. Modelling the hydrological response of a Mediterranean medium-sized headwater basin subject to land cover change: The Cardener River basin (NE Spain). Journal of Hydrology 383:125-134.

Dewson, Z. S., A. B. W. James, and R. G. Death. 2007a. A review of the consequences of decreased flow for instream habitat and macroinvertebrates. Journal of the North American Benthological Society 26:401-415.

Dewson, Z. S., A. B. W. James, and R. G. Death. $2007 \mathrm{~b}$. Invertebrate community responses to experimentally reduced discharge in small streams of different water quality. Journal of the North American Benthological Society 26:754-766.

Dewson, Z. S., A. B. W. James, and R. G. Death. 2007c. Invertebrate responses to short-term water abstraction in small New Zealand streams. Freshwater Biology 52: 357-369. 
Dewson, Z. S., A. B. W. James, and R. G. Death. 2007d. Stream ecosystem functioning under reduced flow conditions. Ecological Applications 17:1797-1808.

DiStefano, R. J., D. D. Magoulick, E. M. Imhoff, and E. R. LARSON. 2009. Imperiled crayfishes use hyporheic zone during seasonal drying of an intermittent stream. Journal of the North American Benthological Society 28:142-152.

DownEs, B. J. 2010. Back to the future: little-used tools and principles of scientific inference can help disentangle effects of multiple stressors on freshwater ecosystems. Freshwater Biology 55:60-79.

DrinKwater, K. F., AND K. T. Frank. 1994. Effects of river regulation and diversion on marine fish and invertebrates. Aquatic Conservation: Freshwater and Marine Ecosystems 4:135-151.

Elliott, J. M. 2000. Pools as refugia for brown trout during two summer droughts: trout responses to thermal and oxygen stress. Journal of Fish Biology 56:938-948.

Elliott, J. M., M. A. Hurley, And J. A. Elliott. 1997. Variable effects of droughts on the density of a sea-trout Salmo trutta population over 30 years. Journal of Applied Ecology 34:1229-1238.

Elsdon, T. S., M. B. N. A. De Bruin, N. J. Diepen, And B. M. GILLANDERS. 2009. Extensive drought negates human influence on nutrients and water quality in estuaries. Science of the Total Environment 407:3033-3043.

Falke, J. A., K. D. Fausch, R. Magelky, A. Aldred, D. S. DuRnFord, L. K. Riley, AND R. OAD. 2011. The role of groundwater pumping and drought in shaping ecological futures for stream fishes in a dryland river basin of the western Great Plains, USA. Ecohydrology 4:682-697.

Feminella, J. W. 1996. Comparison of benthic macroinvertebrate assemblages in small streams along a gradient of flow permanence. Journal of the North American Benthological Society 15:651-669.

Finn, M. A., A. J. Boulton, and B. C. Chessman. 2009. Ecological responses to artificial drought in two Australian rivers with differing water extraction. Fundamental and Applied Limnology/Archiv für Hydrobiologie 175:231-248.

Fischer, S., AND H. Kummer. 2000. Effects of residual flow and habitat fragmentation on distribution and movement of bullhead (Cottus gobio L.) in an alpine stream. Hydrobiologia 422/423, 305-317.

Folt, C. L., C. Y. Chen, M. V. Moore, and J. Burnaford. 1999. Synergism and antagonism among multiple stressors. Limnology and Oceanography 44:864-877.

FraterRigo, J. M., AND J. A. RuSAK. 2008. Disturbance-driven changes in the variability of ecological patterns and processes. Ecology Letters 11:756-770.

Frissell, C. A., W. J. Liss, C. E. Warren, and M. D. Hurley. 1986. A hierarchical framework for stream habitat classification: viewing streams in a watershed context. Environmental Management 10:199-214.

FRITZ, K. M., AND W. K. DodDs. 2005. Harshness: characterisation of intermittent stream habitat over space and time. Marine and Freshwater Research 56:13-23.
Gibson, C. A., J. L. Meyer, N. L. Poff, L. E. Hay, and A. GEORGAKAKOS. 2005. Flow regime alterations under changing climate in two river basins: implications for freshwater ecosystems. River Research and Applications 21:849-864.

Greenwood, M. J., AND A. R. McIntosh. 2010. Low river flow alters the biomass and population structure of a riparian predatory invertebrate. Freshwater Biology 55:20622076.

Groffman, P. M., D. J. Bain, L. E. Band, K. T. Belt, G. S. Brush, J. M. Grove, R. V. Pouyat, I. C. Yesilonis, and W. C. Zipperer. 2003. Down by the riverside: urban riparian ecology. Frontiers in Ecology and the Environment 1:315-321.

GunN, J., AND E. SNUCINS. 2010. Brook charr mortalities during extreme temperature events in Sutton River, Hudson Bay Lowlands, Canada. Hydrobiologia 650:79-84.

Hakala, J. P., and K. J. Hartman. 2004. Drought effect on stream morphology and brook trout (Salvelinus fontinalis) populations in forested headwater streams. Hydrobiologia 515:203-213.

Harvey, B. C., R. J. Nakamoto, and J. L. White. 2006. Reduced streamflow lowers dry-season growth of rainbow trout in a small stream. Transactions of the American Fisheries Society 135:998-1005.

Haxton, H. J., And C. S. Findlay. 2008. Meta-analysis of the impact of water management on aquatic communities. Canadian Journal of Fisheries and Aquatic Sciences 65: 437-447.

Hayes, J. W., N. F. Hughes, and L. H. Kelly. 2007. Processbased modelling of invertebrate drift transport, net energy intake and reach carrying capacity for driftfeeding salmonids. Ecological Modelling 207:171-188.

Howson, T. J., B. J. Robson, And B. D. Mitchell. 2009. Fish assemblage response to rehabilitation of a sand-slugged lowland river. River Research and Applications 25: 1251-1267.

Hughes, D. A. 2005. Hydrological issues associated with the determination of environmental water requirements of ephemeral rivers. River Research and Applications 21: 899-908.

Hughes, L. 2003. Climate change and Australia: trends, projections and impacts. Austral Ecology 28:423-443.

Humphries, P., P. Brown, J. Douglas, A. Pickworth, R. Strongman, K. Hall, and L. Serafini. 2008. Flow-related patterns in abundance and composition of the fish fauna of a degraded Australian lowland river. Freshwater Biology 53:789-813.

Humphries, P., A. J. King, And J. D. Koenn. 1999. Fish, flows and floodplains: links between freshwater fishes and their environment in the Murray-Darling River system, Australia. Environmental Biology of Fishes 56:129-151.

James, A. B. W., Z. S. Dewson, and R. G. Death. 2008a. Do stream macroinvertebrates use instream refugia in response to severe short-term flow reduction in New Zealand streams? Freshwater Biology 53:1316-1334.

James, A. B. W., Z. S. Dewson, and R. G. Death. 2008b. The effect of experimental flow reductions on macroinvertebrate 
drift in natural and streamside channels. River Research and Applications 24:22-35.

James, A. B. W., And A. M. Suren. 2009. The response of invertebrates to a gradient of flow reduction-an instream channel study in a New Zealand lowland river. Freshwater Biology 54:2225-2242.

JoHnson, R. 1998. The forest cycle and low river flows: a review of UK and international studies. Forest Ecology and Management 109:1-7.

JONES, J. B., AND L. A. SMOCK. 1991. Transport and retention of particulate organic matter in two low-gradient headwater streams. Journal of the North American Benthological Society 10:115-126.

Jowett, I. G., J. Richardson, And M. L. Bonnett. 2005. Relationship between flow regime and fish abundances in a gravel-bed river, New Zealand. Journal of Fish Biology 66:1419-1436.

KanNO, Y., AND J. C. VoKOun. 2010. Evaluating effects of water withdrawals and impoundments on fish assemblages in southern New England streams, USA. Fisheries Management and Ecology 17:272-283.

Kemp, P., D. Sear, A. Collins, P. Naden, and I. Jones. 2011. The impacts of fine sediment on riverine fish. Hydrological Processes 25:1800-1821.

Kingsford, R. T., And R. F. Thomas. 1995. The Macquarie Marshes in arid Australia and their waterbirds: a 50year history of decline. Environmental Management 19: 867-878.

Kingsford, R. T., AND R. F. ThOmas. 2004. Destruction of wetlands and waterbird populations by dams and irrigation on the Murrumbidgee River in arid Australia. Environmental Management 34:383-396.

Knights, B. C., B. L. Johnson, And M. B. SANDHEInRICH. 1995. Responses of bluegills and black crappies to dissolved oxygen, temperature, and current in backwater lakes of the upper Mississippi River during winter. North American Journal of Fisheries Management 15:390399.

Komatsu, H., T. Kume, and K. Otsuki. 2009. Changes in low flow with the conversion of a coniferous plantation to a broad-leaved forest in a summer precipitation region, Japan. Ecohydrology 2:164-172.

Komatsu, H., T. Kume, AND K. OtsuKi. 2010. Water resource management in Japan: forest management or dam reservoirs? Journal of Environmental Management 91: 814-823.

Kustu, M. D., Y. FAn, AND A. RовOск. 2010. Large-scale water cycle perturbation due to irrigation pumping in the US High Plains: a synthesis of observed streamflow changes. Journal of Hydrology 390:222-244.

Labbe, T. R., and K. D. Fausch. 2000. Dynamics of intermittent stream habitat regulate persistence of a threatened fish at multiple scales. Ecological Applications 10:1774-1791.

Lafferty, K. D., C. C. Swift, And R. F. Ambrose. 1999. Extirpation and recolonization in a metapopulation of an endangered fish, the tidewater goby. Conservation Biology 13:1447-1453.
LAKE, P. S. 2000. Disturbance, patchiness, and diversity in streams. Journal of the North American Benthological Society 19:573-592.

LAKE, P. S. 2003. Ecological effects of perturbation by drought in flowing waters. Freshwater Biology 48: 1161-1172.

LAKe, P. S., N. Bond, AND P. ReICH. 2007. Linking ecological theory with stream restoration. Freshwater Biology 52: 597-615.

Larned, S. T., T. Datry, D. B. Arscott, And K. Tockner. 2010. Emerging concepts in temporary-river ecology. Freshwater Biology 55:717-738.

LARned, S. T., T. DAtry, AND C. T. Robinson. 2007. Invertebrate and microbial responses to inundation in an ephemeral river reach in New Zealand: effects of preceding dry periods. Aquatic Sciences 69:554-567.

Larson, E. R., D. D. Magoulick, C. Turner, and K. H. LAYCOCK. 2009. Disturbance and species displacement: different tolerances to stream drying and desiccation in a native and an invasive crayfish. Freshwater Biology 54:1899-1908.

Leberfinger, K., I. Bohman, And J. Herrmann. 2010. Drought impact on stream detritivores: experimental effects on leaf litter breakdown and life cycles. Hydrobiologia 652: 247-254.

Ledger, M., R. Harris, P. Armitage, and A. Milner. 2008. Disturbance frequency influences patch dynamics in stream benthic algal communities. Oecologia (Berlin) 155:809-819.

Leigh, C., M. A. Burford, F. Sheldon, And S. E. Bunn. 2010a. Dynamic stability in dry season food webs within tropical floodplain rivers. Marine and Freshwater Research 61:357-368.

Leigh, C., AND F. Sheldon. 2008. Hydrological changes and ecological impacts associated with water resource development in large floodplain rivers in the Australian tropics. River Research and Applications 24:1251-1270.

LeIGH, C., AND F. SHELdON. 2009. Hydrological connectivity drives patterns of macroinvertebrate biodiversity in floodplain rivers of the Australian wet/dry tropics. Freshwater Biology 54:549-571.

Leigh, C., F. Sheldon, R. T. Kingsford, and A. H. Arthington. 2010b. Sequential floods drive 'booms' and wetland persistence in dryland rivers: a synthesis. Marine and Freshwater Research 61:896-908.

Leprieur, F., M. A. Hickey, C. J. Arbuckle, G. P. Closs, S. Brosse, AND C. R. Townsend. 2006. Hydrological disturbance benefits a native fish at the expense of an exotic fish. Journal of Applied Ecology 43:930-939.

Lind, P. R., B. J. Robson, And B. D. Mitchell. 2006. The influence of reduced flow during a drought on patterns of variation in macroinvertebrate assemblages across a spatial hierarchy in two lowland rivers. Freshwater Biology 51:2282-2295.

LivinGSTON, R. J. 1997. Trophic response of estuarine fishes to long-term changes of river runoff. Bulletin of Marine Science 60:984-1004.

Loneragan, N. R., And S. E. Bunn. 1999. River flows and estuarine ecosystems: implications for coastal fisheries 
from a review and a case study of the Logan River, southeast Queensland. Australian Journal of Ecology 24: 431-440.

Lytle, D. A., AND N. L. Poff. 2004. Adaptation to natural flow regimes. Trends in Ecology and Evolution 19: 94-100.

Macedo-Soares, P. H. M. D., A. C. Petry, V. F. Farjalla, and E. P. Caramaschi. 2010. Hydrological connectivity in coastal inland systems: lessons from a Neotropical fish metacommunity. Ecology of Freshwater Fish 19:7-18.

Magalhães, M. F., P. Beja, C. Canas, and M. J. CollaresPereIRA. 2002. Functional heterogeneity of dry-season fish refugia across a Mediterranean catchment: the role of habitat and predation. Freshwater Biology 47: 1919-1934.

Magoulick, D. D., And R. M. KobZa. 2003. The role of refugia for fishes during drought: A review and synthesis. Freshwater Biology 48:1186-1198.

Maheshwari, B. L., K. F. Walker, and T. A. McMahon. 1995. Effects of regulation on the flow regime of the River Murray, Australia. Regulated Rivers: Research and Management 10:15-38.

Mas-Martí, E., E. García-Berthou, S. Sabater, S. Tomanova, AND I. MuÑoz. 2010. Comparing fish assemblages and trophic ecology of permanent and intermittent reaches in a Mediterranean stream. Hydrobiologia 657:167-180.

Matthaei, C. D., J. J. Piggott, and C. R. Townsend. 2010. Multiple stressors in agricultural streams: interactions among sediment addition, nutrient enrichment and water abstraction. Journal of Applied Ecology 47: 639-649.

Matthaei, C. D., and C. R. Townsend. 2000. Long-term effects of local disturbance history on mobile stream invertebrates. Oecologia (Berlin) 125:119-126.

McCann, K. S., J. B. Rasmussen, and J. Umbanhowar. 2005. The dynamics of spatially coupled food webs. Ecology Letters 8:513-523.

McCargo, J. W., and J. T. Peterson. 2010. An evaluation of the influence of seasonal base flow and geomorphic stream characteristics on Coastal Plain stream fish assemblages. Transactions of the American Fisheries Society 139:29-48.

McCluneY, K. E., AND J. L. SABo. 2012. River drying lowers the diversity and alters the composition of an assemblage of desert riparian arthropods. Freshwater Biology 57:91-103.

McDowall, R. M. 1995. Seasonal pulses in migrations of New Zealand diadromous fish and the potential impacts of river mouth closure. New Zealand Journal of Marine and Freshwater Research 29:517-526.

McIntosh, M. D., M. E. Benbow, AND A. J. Burky. 2003. Effect of water removal on introduced caddisflies from a tropical mountain stream. International Journal of Limnology 39:297-306.

McKay, S. F., AND A. J. KING. 2006. Potential ecological effects of water extraction in small, unregulated streams. River Research and Applications 22:1023-1037.

McKerchar, A. I., and R. D. Henderson. 2003. Shifts in flood and low-flow regimes in New Zealand due to inter- decadal climate variations. Hydrological Sciences 48: 637-654.

McMahon, T. A., And B. L. Finlayson. 2003. Droughts and anti-droughts: the low flow hydrology of Australian rivers. Freshwater Biology 48:1147-1160.

McNeil, D. G., AND G. P. Closs. 2007. Behavioural responses of a south-east Australian floodplain fish community to gradual hypoxia. Freshwater Biology 52:412-420.

Miller, S. W., D. Wooster, AND J. Li. 2007. Resistance and resilience of macroinvertebrates to irrigation water withdrawals. Freshwater Biology 52:2494-2510.

Miller, S. W., D. Wooster, And J. L. Li. 2010. Does species trait composition influence macroinvertebrate responses to irrigation water withdrawals: evidence from the Intermountain West, USA. River Research and Applications 26:1261-1280.

Milly, P. C. D., K. A. Dunne, And A. V. Vecchia. 2005. Global pattern of trends in streamflow and water availability in a changing climate. Nature 438:347-350.

Nebel, S., J. L. Porter, And R. T. Kingsford. 2008. Long-term trends of shorebird populations in eastern Australia and impacts of freshwater extraction. Biological Conservation 141:971-980.

Nhiwatiwa, T., T. De Bie, B. Vervaeke, M. Barson, M. Stevens, M. VANHOVE, AND L. BRENDONCK. 2009. Invertebrate communities in dry-season pools of a large subtropical river: patterns and processes. Hydrobiologia 630: 169-186.

Osmundson, D. B., R. J. Ryel, V. L. Lamarra, and J. Pitlick. 2002. Flow-sediment-biota relations: implications for river regulation effects on native fish abundance. Ecological Applications 12:1719-1739.

Owens, P. N., R. J. Batalla, A. J. Collins, B. Gomez, D. M. Hicks, A. J. Horowitz, G. M. Kondolf, M. Marden, M. J. Page, D. H. Peacock, E. L. Petticrew, W. Salomons, and N. A. Trustrum. 2005. Fine-grained sediment in river systems: environmental significance and management issues. River Research and Applications 21:693-717.

Paerl, H. W., N. S. Hall, and E. S. Calandrino. 2011. Controlling harmful cyanobacterial blooms in a world experiencing anthropogenic and climatic-induced change. Science of the Total Environment 409: 1739-1745.

Paerl, H. W., and J. Huisman. 2008. Blooms like it hot. Science 320:57-58.

Poff, N. L., J. D. Allan, M. B. Bain, J. R. Karr, K. L. Prestegando, B. D. Richter, R. E. Sparks, and J. C. Stromberg. 1997. The natural flow regime. BioScience 47: 769-784.

Poff, N. L., B. D. Richter, A. H. Arthington, S. E. Bunn, R. J. Naiman, E. Kendy, M. Acreman, C. Apse, B. P. Bledsoe, M. C. Freeman, J. Henriksen, R. B. Jacobson, J. G. Kennen, D. M. Merritt, J. H. O'Keefe, J. D. Olden, K. Rogers, R. E. Tharme, And A. WARner. 2010. The ecological limits of hydrologic alteration (ELOHA): a new framework for developing regional environmental flow standards. Freshwater Biology 55:147-170.

Poff, N. L., S. ToKar, AND P. Johnson. 1996. Stream hydrological and ecological responses to climate change 
assessed with an artificial neural network. Limnology and Oceanography 41:857-863.

Power, M. E. 1990. Effects of fish in river food webs. Science 250:811-814.

Power, M. E., W. J. Matthews, and A. J. Stewart. 1985. Grazing minnows, piscivorous bass, and stream algae: dynamics of a strong interaction. Ecology 66:1448-1456.

Power, M. E., M. S. Parker, And W. E. Dietrich. 2008. Seasonal reassembly of a river food web: floods, droughts, and impacts of fish. Ecological Monographs 78:263-282.

Preiner, S., I. Drozdowski, M. Schagerl, F. Schiemer, and T. HeIn. 2008. The significance of side-arm connectivity for carbon dynamics of the River Danube, Austria. Freshwater Biology 53:238-252.

Preston, B. L., AND R. N. Jones. 2008. Screening climatic and non-climatic risks to Australian catchments. Geographical Research 46:258-274.

Pusey, B., M. Kennard, And A. Arthington. 2004. Freshwater fishes of north-eastern Australia. CSIRO Publishing, Collingwood, Australia.

Rader, R. B., And T. A. Belish. 1999. Influence of mild to severe flow alterations on invertebrates in three mountain streams. Regulated Rivers: Research and Management 15:353-363.

Rayner, T. S., K. M. Jenkins, And R. T. Kingsford. 2009. Small environmental flows, drought and the role of refugia for freshwater fish in the Macquarie Marshes, arid Australia. Ecohydrology 2:440-453.

Reice, S., R. Wissmar, And R. Naiman. 1990. Disturbance regimes, resilience, and recovery of animal communities and habitats in lotic ecosystems. Environmental Management 14:647-659.

Reid, D. J., G. P. Quinn, P. S. LaKe, and P. Reich. 2008. Terrestrial detritus supports the food webs in lowland intermittent streams of south-eastern Australia: a stable isotope study. Freshwater Biology 53:2036-2050.

Reid, M. A., M. D. Delong, and M. C. Thoms. 2012. The influence of hydrological connectivity on food web structure in floodplain lakes. River Research and Applications 28:827-844.

Reinfelds, I., M. Lincoln-Smith, T. Haeusler, D. Ryan, And I. GRowns. 2010. Hydraulic assessment of environmental flow regimes to facilitate fish passage through natural riffles: Shoalhaven river below Tallowa Dam, New South Wales, Australia. River Research and Applications 26:589-604.

RiIs, T., AND B. J. F. Biggs. 2003. Hydrologic and hydraulic control of macrophyte establishment and performance in streams. Limnology and Oceanography 48:1488-1497.

Riss, T., A. M. Suren, B. Clausen, and K. Sand-Jensen. 2008. Vegetation and flow regime in lowland streams. Freshwater Biology 53:1531-1543.

Riley, W. D., D. L. Maxwell, M. G. Pawson, and M. J. Ives. 2009. The effects of low summer flow on wild salmon Salmo salar, trout Salmo trutta and grayling Thymallus thymallus in a small stream. Freshwater Biology 54: 2581-2599.
Robson, B. J., And T. G. Matthews. 2004. Drought refuges affect algal recolonization in intermittent streams. River Research and Applications 20:753-763.

Rogers, M. W., M. S. Allen, AND M. D. Jones. 2005. Relationship between river surface level and fish assemblage in the Ocklawaha River, Florida. River Research and Applications 21:501-511.

SAlmaso, N., AND M. BRAIONI. 2008. Factors controlling the seasonal development and distribution of the phytoplankton community in the lowland course of a large river in Northern Italy (River Adige). Aquatic Ecology 42:533-545.

SCHEFFER, M., AND S. R. CARPENTER. 2003. Catastrophic regime shifts in ecosystems: linking theory to observation. Trends in Ecology and Evolution 18:648-656.

Sedell, J. R., G. H. Reeves, F. R. Hauer, J. A. Stanford, and C. P. Hawkins. 1990. Role of refugia in recovery from disturbances: modern fragmented and disconnected river systems. Environmental Management 14:711-724.

Selberg, C. D., L. A. Eby, and L. B. Crowder. 2001. Hypoxia in the Neuse River estuary: responses of blue crabs and crabbers. North American Journal of Fisheries Management 21:358-366.

Sheldon, F., S. E. Bunn, J. M. Hughes, A. H. Arthington, S. R. Balcombe, and C. S. Fellows. 2010. Ecological roles and threats to aquatic refugia in arid landscapes: dryland river waterholes. Marine and Freshwater Research 61: 885-895.

Sheldon, F., AND C. S. Fellows. 2010. Water quality in two Australian dryland rivers: spatial and temporal variability and the role of flow. Marine and Freshwater Research 61:864-874.

Siriwardena, L., B. L. Finlayson, and T. A. McMahon. 2006. The impact of land use change on catchment hydrology in large catchments: the Comet River, central Queensland, Australia. Journal of Hydrology 326:199-214.

SMAKHTIN, V. U. 2001. Low flow hydrology: a review. Journal of Hydrology 240:147-186.

SNADdON, C. D., AND B. R. DAvies. 1998. A preliminary assessment of the effects of a small South African interbasin water transfer on discharge and invertebrate community structure. Regulated Rivers: Research and Management 14:421-441.

Sotiropoulos, J. C., K. H. Nislow, And M. R. Ross. 2006. Brook trout, Salvelinus fontinalis, microhabitat selection and diet under low summer stream flows. Fisheries Management and Ecology 13:149-155.

Sponseller, R. A., N. B. Grimm, A. J. Boulton, and J. L. Sabo. 2010. Responses of macroinvertebrate communities to long-term flow variability in a Sonoran Desert stream. Global Change Biology 16:2891-2900.

Staunton-Smith, J., J. B. Robins, D. G. Mayer, M. J. Sellin, and I. A. Halliday. 2004. Does the quantity and timing of fresh water flowing into a dry tropical estuary affect year-class strength of barramundi (Lates calcarifer)? Marine and Freshwater Research 55:787-797.

Stromberg, J. C., V. B. Beauchamp, M. D. Dixon, S. J. Lite, and C. PARAdZick. 2007. Importance of low-flow and highflow characteristics to restoration of riparian vegetation 
along rivers in arid south-western United States. Freshwater Biology 52:651-679.

Stubiington, R. 2012. The hyporheic zone as an invertebrate refuge: a review of variability in space, time, taxa and behaviour. Marine and Freshwater Research 63:293-311.

Stubington, R., A. Greenwood, P. Wood, P. Armitage, J. GunN, AND A. Robertson. 2009. The response of perennial and temporary headwater stream invertebrate communities to hydrological extremes. Hydrobiologia 630:299-312.

Stubbington, R., P. J. Wood, I. Reid, and J. Gunn. 2011. Benthic and hyporheic invertebrate community responses to seasonal flow recession in a groundwaterdominated stream. Ecohydrology 4:500-511.

Suen, J. 2010. Potential impacts to freshwater ecosystems caused by flow regime alteration under changing climate conditions in Taiwan. Hydrobiologia 649: 115-128.

Suren, A. M., B. J. F. Biggs, M. J. Duncan, L. Bergey, and P. LAMBERT. 2003a. Benthic community dynamics during summer low-flows in two rivers of contrasting enrichment 2. Invertebrates. New Zealand Journal of Marine and Freshwater Research 37:71-83.

Suren, A. M., B. J. F. Biggs, C. Kilroy, and L. Bergey. 2003b. Benthic community dynamics during summer lowflows in two rivers of contrasting enrichment 1. Periphyton. New Zealand Journal of Marine and Freshwater Research 37:53-70.

SuREN, A. M., AND T. RiIs. 2010. The effects of plant growth on stream invertebrate communities during low flow: a conceptual model. Journal of the North American Benthological Society 29:711-724.

Suttle, K. B., M. E. Power, J. M. Levine, And C. McNeely. 2004. How fine sediment in riverbeds impairs growth and survival of juvenile salmonids. Ecological Applications 14:969-974.

SWANK, W. T., J. M. Vose, AND K. J. Elliott. 2001. Long-term hydrologic and water quality responses following commercial clearcutting of mixed hardwoods on a southern Appalachian catchment. Forest Ecology and Management 143:163-178.

Teichert, M. A. K., E. Kvingedal, T. Forseth, O. Ugedal, and A. G. Finstad. 2010. Effects of discharge and local density on the growth of juvenile Atlantic salmon Salmo salar. Journal of Fish Biology 76:1751-1769.

Thomaz, S., L. Bini, And R. Bozelli. 2007. Floods increase similarity among aquatic habitats in river-floodplain systems. Hydrobiologia 579:1-13.

Tockner, K., D. Pennetzdorfer, N. Reiner, F. Schiemer, AND J. V. WARD. 1999. Hydrological connectivity, and the exchange of organic matter and nutrients in a dynamic river-floodplain system (Danube, Austria). Freshwater Biology 41:521-535.

Townsend, S. A., And A. V. Padovan. 2005. The seasonal accrual and loss of benthic algae (Spirogyra) in the Daly River, an oligotrophic river in tropical Australia. Marine and Freshwater Research 56:317-327.

Townsend, S. A., M. Przybylska, And M. Miloshis. 2012. Phytoplankton composition and constraints to biomass in the middle reaches of an Australian tropical river during base flow. Marine and Freshwater Research 63: 48-59.

van der Nat, D., A. P. Schmidt, K. Tockner, P. J. Edwards, AND J. V. WARD. 2002. Inundation dynamics in braided floodplains: Tagliamento River, northeast Italy. Ecosystems 5:636-647.

van Vliet, M. T. H., and J. J. G. Zwolsman. 2008. Impact of summer droughts on the water quality of the Meuse River. Journal of Hydrology 353:1-17.

Vinagre, C., J. Salgado, H. Cabral, and M. Costa. 2011. Food web structure and habitat connectivity in fish estuarine nurseries-impact of river flow. Estuaries and Coasts 34:663-674.

Vorwerk, P. D., A. W. Paterson, P. W. Froneman, and A. K. WhitFIELD. 2009. Increased abundance of two important sport fishery species following renewed river flow into a freshwater-deprived South African estuary. Fisheries Management and Ecology 16:420-423.

Walsh, C. J., A. H. Roy, J. W. Feminella, P. D. Cottingham, P. M. Groffman, and R. P. Morgan. 2005. The urban stream syndrome: current knowledge and the search for a cure. Journal of the North American Benthological Society 24:706-723.

Walters, A. W., AND D. M. Post. 2008. An experimental disturbance alters fish size structure but not food chain length in streams. Ecology 89:3261-3267.

Walters, A. W., AND D. M. Post. 2011. How low can you go? Impacts of a low-flow disturbance on aquatic insect communities. Ecological Applications 21:163-174.

Wood, P. J., And P. D. Armitage. 2004. The response of the macroinvertebrate community to low-flow variability and supra-seasonal drought within a groundwater dominated stream. Archiv für Hydrobiologie 161:1-20.

Wood, P. J., A. J. Boulton, S. Little, And R. Stubbington. 2010. Is the hyporheic zone a refugium for aquatic macroinvertebrates during severe low flow conditions? Fundamental and Applied Limnology/Archiv für Hydrobiologie 176:377-390.

Wootton, J. T., M. S. Parker, And M. E. Power. 1996. Effects of disturbance on river food webs. Science 273: 1558-1560.

Xenopoulos, M. A., D. M. Lodge, J. Alcamo, M. Märker, K. Schulze, AND D. P. VAN VuUREN. 2005. Scenarios of freshwater fish extinctions from climate change and water withdrawal. Global Change Biology 11: 1557-1564.

Xu, C. L., B. H. Letcher, And K. H. Nislow. 2010. Sizedependent survival of brook trout Salvelinus fontinalis in summer: effects of water temperature and stream flow. Journal of Fish Biology 76:2342-2369.

Ylla, I., I. Sanpera-Calbet, E. VÁzQuez, A. Romaní, I. Muñoz, A. Butturini, And S. SABAter. 2010. Organic matter availability during pre- and post-drought periods in a Mediterranean stream. Hydrobiologia 657:217-232.

Received: 9 January 2012 Accepted: 10 August 2012 